\title{
The challenges of measuring bleeding outcomes in clinical trials of platelet transfusions
}

\section{Short title: Measuring bleeding in platelet transfusion trials}

Authors: LJ Estcourt ${ }^{1}$, N Heddle ${ }^{2}$, R Kaufman ${ }^{3}$, J McCullough ${ }^{4}$, MF Murphy ${ }^{1}$, S Slichter ${ }^{5}$, EM Wood ${ }^{6}$, SJ Stanworth ${ }^{1}$, On behalf of the BEST (Biomedical Excellence for Safer Transfusion) Collaborative

1. NHS Blood and Transplant/Oxford University Hospitals NHS Trust, and the NIHR Biomedical Research Centre, John Radcliffe Hospital, Oxford, UK.

2. Department of Medicine, McMaster University, Hamilton, ON Canada

3. Harvard Medical School Blood Bank, Amory 260 Brigham and Women's Hospital, 75 Francis Street, Boston, MA 02115

4. University of Minnesota, 420 Delaware Street SE, Minneapolis, MN 55455

5. Puget Sound Blood Center and University of Washington School of Medicine, Seattle, Washington, US

6. Australian Red Cross Blood Service and Department of Clinical Haematology, Monash University, Melbourne, Australia

Correspondence: Dr Lise J Estcourt, NHS Blood and Transplant, Level 2, John Radcliffe Hospital, Oxford, OX3 9BQ, United Kingdom; lise.estcourt@nhsbt.nhs.uk

Funding This study was supported by the BEST Collaborative

\section{Conflict of Interest}

The authors declare that they have no conflicts of interest relevant to the manuscript submitted to Transfusion. Several authors are PIs on included trials

Word count

Abstract: 249

Text: 4,452

Tables and figures:

6 Tables

1 Figure

On-line appendices : 4

References: 46 


\begin{abstract}
Background. Many platelet transfusion trials now use bleeding as a primary outcome; however, previous studies have shown a wide variation in the amount (5-70\%) and type of bleeding documented. Differences in the way bleeding has been identified, recorded and graded may account for some of this variability. This study's aim was to compare trials' methodology to document and grade bleeding.
\end{abstract}

Study Design and Methods. Data were collected via three methods: a review of study publications; study case-report forms and a questionnaire sent to the authors. Authors of randomized-controlled-trials of platelet transfusion, that used bleeding as an outcome measure, were identified from the searches reported by two recent systematic reviews. Twentyfour authors were contacted, and 13 agreed to participate. Data submitted were reviewed and summarized.

Results. More recent studies with trained bleeding assessors, detailed documentation and expanded grading systems have reported higher overall levels of bleeding. The WHO grading system was widely used to grade bleeding, but there was no consistency in the bleeding grade definitions. For example, bleeding classified as grade 2 in some studies (spreading petechiae), was classified as grade 1 in other studies.

Conclusions. This study has highlighted differences in the methodology of recording and grading bleeding which may account for some of the variation in reported bleeding rates. To ensure differences between studies can be attributed to trial interventions or types of participant included this study group is developing: consensus bleeding definitions; a standardized approach to record and grade bleeding; and guide-notes to educate/train bleeding assessors.

Key Words: Platelet Transfusion; Health Research Methodology 


\section{Introduction}

Many recent clinical trials of platelet transfusion therapy have used bleeding as a primary endpoint ${ }^{1-9}$. There are two important considerations when bleeding is used as an outcome measure: the documentation of signs and symptoms of bleeding; and, the translation of this information into a clinically meaningful score or grade. This is fundamental to the robustness of results reported in these trials, and valid comparisons between studies can only be drawn if similar outcomes are being compared. Therefore, if bleeding is to be used as a main outcome measure, it is important that it is defined and documented in a consistent and standardized way.

However, the assessment of bleeding involves an element of subjectivity, and the literature indicates wide variability in the methods by which bleeding has been assessed and documented in clinical trials of platelet transfusion. Taken together, these factors may be responsible, in part, for differences in the reported baseline bleeding rates between studies, which have varied in randomized-controlled trials from $5 \%{ }^{10}$ to $70 \%^{5}$. Different trials have taken different approaches in an attempt to minimize this bias, such as the use of a standardized tool for assessing bleeding ${ }^{6}$; training of staff 3 ; or grading of bleeding ${ }^{4-6}{ }^{11}$.

Although variability in the documentation and grading of bleeding is known to exist, there has not been a systematic summary of the approaches used to document and grade bleeding in platelet transfusion trials. Such a summary would help the transfusion medicine community to understand current practices and guide recommendations for a consistent and standardized approach when bleeding is used as an outcome in platelet transfusion trials. The ultimate goal of this project, undertaken by members of the Biomedical Excellence for Safer Transfusion (BEST) Collaborative, was to develop recommendations and/or a standardized case report form (CRF) to assist primary investigators when bleeding is used as an outcome in future clinical trials and to facilitate comparison of outcomes between studies for reviewers and readers. These recommendations/CRF should minimize some of the potential problems associated with the reliability 
of this important clinical endpoint. As the first step to achieve this goal, Information was sought from the lead investigators of clinical trials of platelet transfusions, with the specific aims to:

1)describe the methods used in the trial protocol to document bleeding; and,

2) describe the methods for grading bleeding, including the assignment of bleeding grades and validation of the process.

\section{Materials and Methods}

\section{Identification of studies}

To identify clinical platelet studies we used the search strategies (Appendix 1) for a recently updated Cochrane review of prophylactic platelet transfusions ${ }^{12}$ and that reported by the BEST Collaborative for their systematic assessment of quality of reporting for platelet transfusion studies ${ }^{13}$. The search was limited to randomized controlled trials (RCTs) in humans that reported bleeding as a primary or secondary outcome. The primary authors of all identified trials were contacted and were invited to participate in the study by sharing copies of their bleeding assessment tool case report forms (CRFs) together with any protocol, standard operating procedure, or guidance notes describing the procedures for bleeding assessment and documentation. The primary author was contacted up to three times. If the primary author did not respond a second author was also contacted up to three times.

\section{Data collection}

Data for analysis were taken from three sources. Publications associated with each study were reviewed. The CRFs and any guidance notes were reviewed to assess how the study teams documented signs, symptoms and site of bleeding, severity (grade) of bleeding, and treatment of any bleeding episodes. This was supplemented by information from a questionnaire (Appendix 2 - online only) developed by the BEST Collaborative Project Group and piloted by three of the study authors. The questionnaire was circulated to all authors who had agreed to participate and had provided copies of their CRFs. The questionnaire asked about how study data were collected, the methods used for standardization and training, and how bleeding was graded. 
Summary data elements were identified by the investigators, and one investigator (LE) reviewed all submitted material including the primary study manuscripts and captured the relevant data summarizing it in table format. The information from each study was then sent to the study author for verification of accuracy and completion of missing data.

\section{Analysis}

The overall analysis was descriptive with results presented as percentages for categorical data. Missing data were reflected by variation in denominators. The study team reviewed all data summaries and developed recommendations via consensus.

\section{Results}

\section{Overview}

The results of the search strategy are shown in Figure 1. Four of the authors, who had published studies in the 1970 s and 80 s, had retired or died ${ }^{14-17}$. Fifteen primary authors responded, of these, 13 authors ${ }^{1-8}$ 20-24 agreed to participate. Nine secondary authors ${ }^{1025-32}$ were contacted, one responded, but had just retired ${ }^{25}$. Two sets of two authors ${ }^{362124}$ worked in close collaboration and used the same CRFs and one author ${ }^{33} 34$ had two different CRFs for separate studies.

\section{Baseline Characteristics of identified studies (Tables 1 \& 2)}

Of the 11 authors who returned CRFs (Figure 1), eight were the primary authors of multi-center randomized controlled trials and three of these studies were multi-national. Studies were based in Australia, Canada, France, Germany, Italy, Netherlands, Norway, Spain, Sweden, UK and USA. Study size ranged from 82 to 1351 participants. The majority of the CRFs (9/12) and questionnaires (9/11) were from studies performed from 2000 onwards.

\section{Methods of Recording Bleeding (Table A Appendix 3)}

Based on the 11 questionnaires returned, the bleeding assessment consisted of at least a formalized bleeding assessment and a clinical examination of the patient. In all but two cases (9/11) this was done on a daily basis. One study performed the assessment twice a day ${ }^{8}$, and the other study ${ }^{23}$ performed the 
assessment twice daily on the day of any platelet transfusion and once daily on the day following the platelet transfusion. In $7^{1-356934}$ of the 11 studies the bleeding assessment was performed at the same time each day.

In 6 of the 11 studies $^{2} 568933$, the bleeding assessment was performed by trained research nurses or other research investigators at least part of the time. In 4 out of 11 studies the bleeding assessor was reported to be blinded to treatment allocation ${ }^{35235}$. In only one study was the effectiveness of this blinding assessed ${ }^{3}$, where research nurses were asked to detect study units from a panel of 10 platelet components (a mixture of study and conventional units) and then complete a questionnaire.

\section{Site and Severity of bleeding (Tables $3 \& 4$ )}

Information on the CRFs in all studies was collected using a mixture of check boxes (yes/no) and open-ended questions (which may be more difficult to analyze). In all of the studies conducted during the last decade $(9 / 12)^{2} 35-9222333$, the CRFs consisted of tick box or Yes/No responses although $(2 / 9)^{723}$ had a significant number ( $>25 \%$ ) of open-ended questions.

There was significant variability among CRFs in the amount of detail related to the site and severity of bleeding (Table 3). Definitions appeared to vary most between studies in relation to bleeding into the skin and subcutaneous tissue. Pathology ${ }^{37}$ and dermatology ${ }^{38}$ textbooks differentiate between petechiae, purpura and ecchymoses according to the size of the hemorrhage into the skin (petechiae $<2 \mathrm{~mm}$, purpura $2 \mathrm{~mm}$ to $10 \mathrm{~mm}$ and ecchymoses $>10 \mathrm{~mm}$ ) and all are forms of hematoma. However, the definitions of these variables in many of the studies differed from each other and did not conform with textbook definitions. The term purpura was often used to define any type of skin bleeding larger than petechiae. Three studies distinguished between purpura that were less than or greater than one inch ${ }^{3}{ }^{34}$. One study distinguished between hematomas that were less than or greater than $1 \mathrm{~cm}^{23}$. Two studies ${ }^{6}$ distinguished between purpura and ecchymoses with the distinction between the two being $2 \mathrm{~cm}^{6}$ or 1 inch 2 .

All studies provided suggested definitions for different severity scores of bleeding at some anatomical sites, but the details varied between studies (Table 3). For example, all studies asked about bleeding from the 
mouth, but three did not ask about the duration of bleeding ${ }^{42}{ }^{33}$. Two studies asked about red blood cells (RBCs) in CSF (cerebro-spinal fluid) only seen on microscopy ${ }^{54}$, and one study ${ }^{5}$ asked about RBCs in other body cavity fluid on microscopic examination. Ten studies 23 5-9 22233334 assessed bleeding severity by the need for RBC transfusion to treat bleeding above routine requirements (83.3\%; 10/12). Fifty per cent (6/12) of the studies 56233436 required information on whether bleeding was associated with hemodynamic instability. Twenty-five per cent (3/12) of the studies documented whether bleeding was associated with a significant fall in hemoglobin $(\mathrm{Hb})^{5} 7^{34}$. Two studies ${ }^{34}$ also defined severity of bleeding by need for interventions other than RBC transfusion e.g. other medications or procedures (Table 4).

None of the platelet threshold studies ${ }^{14} 22$ (Table 2) classified skin bleeding as clinically significant bleeding, and all these studies had a lower rate of bleeding than the platelet dose studies ${ }^{2} 5$ and studies assessing pathogen-reduction technologies ${ }^{333}$.

\section{Methods of achieving consistency in the assessment of bleeding}

Eight $^{2-682334}$ of the 11 studies reported the training of bleeding outcome assessors, prior to commencement of the study. Four ${ }^{36823}$ of the studies provided further training once the study had started, but only two ${ }^{36}$ of these studies indicated that training occurred on a regular basis. Six of the studies ${ }^{2-6} 8$ reported more than one trained bleeding assessor at each site and four ${ }^{2} 356$ of these mentioned that trained assessors were present at weekends or that there was a back-up assessor to cover sick leave.

Seven ${ }^{2-6} 2334$ of the studies reported providing guidance notes to the bleeding assessors in addition to the actual CRFs. However there was great variability in the level of detail provided in these notes for the five studies that shared this information. Two ${ }^{63}$ provided practical information on how to complete the CRFs and two ${ }^{634}$ included 'easy to read' definitions of the different types of bleeding. For two studies ${ }^{23}$ the notes were expanded versions of the World Health Organization (WHO) grading criteria.

Duplicate bleeding assessments were performed in three ${ }^{168}$ of the studies. This was performed in $50 \%$ of cases for one study ${ }^{1}$, approximately $10 \%$ of cases for the second study ${ }^{6}$ and only in cases of severe or lifethreatening bleeding for the third study ${ }^{8}$. Whether the second bleeding assessor was blinded from the 
results of the first bleeding assessor was not asked in the questionnaire. In all three cases the results of these assessments were fed back to the assessors, as a form of on-going education. The results of two of these studies ${ }^{69}$ have not yet been published. Two studies reported other specific methods of decreasing inter-observer variability. These included dummy bleeding assessment scenarios during training days ${ }^{6}$ and clinical investigator oversight and final review of all daily hemostatic assessment forms ${ }^{3}$. (In this study, all CRFs were monitored against primary source documents by Contract Research Organization (CRO) research monitors; discrepant data were queried and reviewed by the clinical investigator at each site; and the primary clinical investigator at each site rendered the final assessment of daily bleeding grade.)

All of the studies ${ }^{235}$ that have reported bleeding rates over $50 \%$ had specially trained research nurses.

\section{Grading of Bleeding}

Six of the 11 authors used the WHO grading system ${ }^{39}$ in their most recent platelet transfusion studies 2562123 ${ }^{34}$. Three of the authors reported using the Rebulla system ${ }^{4}$ or a variant of this scale ${ }^{722}$. One study used a modified scoring system that included elements of the WHO and Rebulla classifications ${ }^{8}$. One study ${ }^{1}$ used a system devised by Ajani et al ${ }^{40}$, but this has not been used in more recent platelet transfusion studies.

Different grading systems can lead to different baseline levels of bleeding. This can be seen in data from the SPRINT study (Table 5). Patients were graded daily using the WHO grading system but the trained study personnel also reported any bleeding as a side-effect using the Common Toxicity Criteria for Adverse Events (CTCAE) system. Although the overall incidence of bleeding was similar between the two grading systems ${ }^{41}$, which reflects no difference in the number of bleeds being reported using the two systems, there were significant differences in how they were graded. There were fewer grade 2, 3 or 4 bleeds using the CTCAE system, which may be explained by the observation that occult blood in the urine could be graded as WHO grade 2 and that, apart from bleeding into the skin, to classify bleeding as CTCAE grade 2 it required an intervention of some sort.

WHO grading system ${ }^{39}$ (Table B Appendix 3) 
The WHO system is now used in the majority of studies. The original grading system ${ }^{39}$ classified petechiae as grade 1; mild blood loss as grade 2; gross blood loss as grade 3 and debilitating blood loss as grade 4 . None of the terms were defined further. All of the authors who defined significant bleeding classified it as grade 2 or above. All of the authors who defined life-threatening bleeding classified it as grade 4 . But, all of the authors who were using the WHO grading system had refined it from the original formulation ${ }^{39}$ in different ways. This led to variability in the way the same bleed would be graded between different studies.

Some of these differences could lead to the same bleed being categorized as grade 2 in one study and grade 1 or no bleeding in another study. For example, $3 / 6$ studies $^{2}{ }^{23}$ defined occult blood $>1+$ in the urine as WHO grade 2 bleeding. Three of six studies ${ }^{3623}$ defined grade 2 vaginal bleeding as bleeding saturating more than 2 pads per day, whereas the other 3 studies $^{25}{ }^{34}$ defined abnormal vaginal bleeding more than spotting as grade 2 bleeding. Three of six studies ${ }^{5634}$ defined epistaxis that lasted more than 30 minutes as grade 2 bleeding whereas the other $50 \%^{2323}$ only regarded bleeding that lasted an hour as grade 2 bleeding. There was also variability in the way that petechiae, purpura, hematomas and ecchymoses were defined between studies. Two of the studies defined diffuse petechiae as WHO grade 2 bleeding ${ }^{3}$. Retinal bleeding that did not cause visual compromise was classified as grade 1 in one study ${ }^{3}$ and grade 2 in the other five studies ${ }^{25} 6$ ${ }^{23} 34$. Finally, the definition of hemodynamic compromise varied between studies: two studies ${ }^{54}$ categorized a drop in systolic or diastolic blood pressure of $30 \mathrm{mmHg}$ as a grade 3 bleed; whereas, two further studies ${ }^{36}$ regarded this as a grade 4 bleed.

\section{RBC transfusion requirements}

Ten of the 11 authors ${ }^{1-68922233334}$ used RBC requirements to grade bleeding, and four of these authors ${ }^{148934}$ reported a standardized transfusion policy operating in the study (only one $\mathrm{e}^{34}$ of the six authors who used the WHO grading system reported a standardized transfusion policy). Without a standardized policy the same type of bleed could be graded as grade 2 or 3 depending on the transfusion decision by the treating physician/research center. 


\section{Conversion of bleeding data into a bleeding grade (Table C Appendix 3)}

The majority of studies assigned a bleeding grade manually (9/11). Three studies (3/11) assigned the grade using a validated computer algorithm ${ }^{5634}$ and two $^{56}$ of these used this single system of grading. In one of these studies ${ }^{6}$ validation of the algorithm was performed by comparing 100 patients via both manual and computer methods, the other study ${ }^{5}$ did not report the method of validation. The third study ${ }^{34}$ performed both manual and computer algorithm methods of grading bleeding. Of those that graded bleeding manually only two studies ${ }^{43}$ did not check the grading using a second person or method. All of the studies that checked their results via a second method or person resolved any disagreement by adjudication. This adjudication could have involved: debate between study personnel (four studies ${ }^{1833}$ ); referral to the Chief Investigator/Principal Investigator (two studies ${ }^{3}$ ); or referral to an independent third party/parties (two studies $\left.^{27}\right)$.

\section{Discussion}

The methods used to assess, document and grade bleeding in platelet transfusion trials display considerable heterogeneity, yet the outcome of bleeding is increasingly defined as a primary outcome. The variability extended from the nature of the staff acting as bleeding assessors (e.g. trained and blinded research nurses), type of bleeding data recorded, through to the different methods for assigning bleeding grade (e.g. computer algorithm vs. manual). A key question is to what extent these different methodological approaches contribute to the variability in the frequencies of bleeding reported between studies. Although no formal analysis of the effect of the methodological differences on the reported bleeding outcomes were possible in this study, some general trends in the variations of bleeding outcomes can be identified, which have implications for researchers and their readers.

Variability in bleeding frequencies between studies was most apparent for minor and moderate bleeds (WHO grade $1 \& 2$ bleeding) (Table 2). This raises questions about how different research groups have 
defined these types of bleeds, and what information, including education and training, is provided for bleeding assessors. As shown in Table 3, different studies have taken different approaches to define sites and severity of bleeding. These variations could affect the number of grade 2 bleeds and may explain some of the variability in the number of WHO grade 2 bleeds between different studies (Table 2). For example, bleeding classified as grade 2 in some studies (microscopic blood in urine or spreading petechiae), was not classified at a similar grade of bleeding (grade 0 or 1, respectively) in another study.

Another reason for variation in rates of bleeding relates to how different research groups have provided education and training for bleeding assessors. Only a few trials indicated the preparation of specific information sheets with examples of different bleeding events, as a practical means of supporting researchers and ensuring consistent application of the different definitions. Dedicated training with guidance notes for researchers and follow-up training would be further expected to reduce inter-observer variability, but processes for providing specific training and education to assessors were only described in three studies by McCullough ${ }^{3}$, Stanworth ${ }^{6}$ and Wandt $^{8}{ }^{9}$. The use of dedicated research staff might facilitate any training and education in a trial, as for the PLADO ${ }^{5}, \mathrm{SPRINT}^{3}, \mathrm{TOPPS}^{6}$ and StoP ${ }^{2}$ trials, but the use of research staff will presumably inflate the cost of the overall trial by comparison to using ward or clinical staff.

All trials converted bleeding data into bleeding grades. Although most of the recent studies used the WHO classification to grade bleeding, each study appeared to describe variations in the criteria. Although often minor, these variations could affect the number of grade 1 and 2 bleeds reported between different studies (Table 2). For example, all studies that did not classify skin bleeding as grade 2 bleeding had a lower overall rate of bleeding. Also, the baseline rate of bleeding differed between the StoP ${ }^{2}$ and PLADO $^{5}$ studies. Part of this difference may be explained by differences in the grading of epistaxis (1 hour vs. 30mins) and skin bleeding (purpura/ecchymoses of $10 \mathrm{~cm}$ vs. $2.54 \mathrm{~cm}$ ) that was classified as grade 2 bleeding. Some studies reported that occult bleeding was important to document and grade, for example, the SPRINT study ${ }^{3}$ graded fecal occult blood and hematuria that was only dipstick positive as bleeding, however, the Kerkhoff ${ }^{33}$ study 
did not. In the SPRINT ${ }^{3}$ study the most common type of bleeding was genitourinary (32.1\%), whereas other studies that did not document microscopic blood loss had a much lower rate of genitourinary bleeding. For example, in studies that included skin bleeding as grade 2 bleeding muco-cutaneous bleeding was the most common (Wandt ${ }^{8}{ }^{9}$ ), whereas gastrointestinal blood loss was the most common type in those that excluded skin bleeding (Rebulla ${ }^{4}$;inmouth ${ }^{7}$ ).

Most studies reported using a manual method of bleeding adjudication for assigning grade, but few data are available about how this works in practice and experience from the recent StoP trial $^{2}$ suggests real difficulties achieving consensus. Computer algorithms may provide a more consistent method of assigning bleeding grade, but without details on validation of these methods, it is unclear exactly whether computer algorithms deliver more accurate grading than manual methods, although reproducibility is likely to be higher than manual methods.

Only a few studies included the need for specific interventions as a guide to severity. The use of interventions to manage bleeding is one of the first decisions to be made by clinicians when faced by a patient with bleeding. However, a difficulty with using this approach might be the desire to minimize interventions in these patients who are often profoundly neutropenic (e.g. endoscopy/colonoscopy), and the inevitable variation in access to interventions and which may also change with time e.g. use of recombinant factor VIla where the evidence for overall lack of effectiveness has become clearer ${ }^{42}$.

\section{Implications for researchers}

The analysis of methodologies in this study has raised a number of points which should help trialists, in the future, at the study design stage, when training staff and when reporting results. Whilst it seems obvious that study protocols should provide clear definitions of all relevant bleeds, wider agreement and consensus on the definitions of bleeding events and which bleeding events are clinically meaningful would help improve the consistency of reporting, and support direct comparison of results between studies. Some of these key areas for agreement could be fairly easily considered by the international community. For 
example, some protocols suggest that all petechiae are WHO grade 1, and clinically insignificant; but it seems likely that many clinical hematologists when faced with a patient with spreading or generalized petechiae and severe thrombocytopenia would treat the patient with a platelet transfusion. It also seems difficult to suggest that nose bleeding up to 1 hour is of no importance or concern, particularly to the patient. However, some studies always grade this type of bleeding as WHO 1 and therefore clinically insignificant.

Some studies have collected information on occult bleeding. But if these types of bleeds are considered important to collect, which is perhaps open to discussion, then specific questions on the CRFs need to capture this information, to minimize any risk of under-reporting (this has been seen in other settings, for example the systematic under-reporting of acute lung injury ${ }^{43}$ ).

These issues also raise the question as to whose perception should be considered if standardization is attempted: the physicians, the patients, or both? There has been little reported work evaluating how patients feel about the different types of bleeding, particularly more minor or moderate muco-cutaneous bleeding. These examples indicate the need for research to explore and understand differences between the clinician and the patient's perception of bleeding events. Patient perception of bleeding is especially important in those studies that rely on patients recording bleeding outcomes in the outpatient setting, away from medical oversight.

The methods of data collection need to be considered in a trial protocol, including the role of bleeding assessors. The method of training of staff or researchers undertaking bleeding assessments has been poorly documented in many trials. Assessment of bleeding will always be subjective, to a degree, and therefore ways to improve consistency within and between studies is crucial, and trial protocols should describe the training programs and strategies taken to support consistency in the recording of bleeding. Achieving blinding in platelet transfusion studies can be challenging, unless the platelet components are identical, due to problems with blinding the medical staff caring for the patient. The only blinding that is likely to be readily achievable is that of the bleeding assessor, if they are independent from the care of the patient. However, 
the bleeding assessor is also usually the person collecting the clinical and laboratory transfusion data, and therefore studies comparing prophylactic versus therapeutic policies or platelet transfusion thresholds would require the data for bleeding and transfusion to be collected by separate individuals to maintain blinding. This would have major resource implications.

The methodology for defining and assigning bleeding grades is important, and any differences from previous trials should be indicated. The WHO score was developed as a tool for adverse event reporting in cancer patients, and although widely used, it has never been validated for specific use in clinical trials of transfusion. However, its widespread use and acceptance may provide a degree of post-hoc validation. Indeed, one study has shown good agreement (90\%; 136/151 days) between self-assessment and medical grading of bleeding ${ }^{44}$, if the presence or absence of microscopic hematuria was excluded. If it is to continue to serve as the international consensus scoring tool for this purpose agreement on the exact format of the WHO grading score should be considered by the international research community, as this would remove one level of uncertainty when comparing results between studies. For example, consensus on the need to collect data on occult types of bleeding or these could be identified separately e.g. grade $1^{\text {Occult }}$ or grade $2^{\text {Occult }}$. An alternative would be to develop and use a new type of bleeding scale which has recently been reported, although with any new scale it would take time to assess its clinical acceptability ${ }^{45}$. At a minimum, if bleeding is a main outcome measure ${ }^{46}$, all trials of platelet transfusion should include specific information on bleeding grade definitions and educational/training support.

\section{Limitations of this study}

Although this study aimed to review all randomized-controlled platelet transfusion trials, it was limited by only a proportion of authors responding to a request for the CRFs or completion of the questionnaire, despite repeated requests. Despite this caveat, information was obtained from the majority of the major researchers in this field and therefore this study represents a comprehensive picture of the current methodologies. 
The analysis in this study was descriptive; and this study was not designed to quantify risk factors responsible for variability in bleeding. Estimates of how much the differences in grading could affect bleeding rates, could only be undertaken if individual patient data were available, and recorded in sufficient detail for different grading systems to be compared.

\section{Summary}

This review has identified important differences in how the recording of signs and symptoms of bleeding is documented and how bleeding grades are assigned between studies. Consensus on optimal methodology could include: standardized case report forms that all investigators could use to record signs and symptoms of bleeding as well as interventions to treat bleeding, and a grading scale that is clinically relevant and can be reproducibly applied (Table 6). These steps form part of an on-going program of research by this project group. 


\section{Acknowledgements}

\section{Collaborators}

The authors would like to thank all study authors who supplied CRFs and completed the questionnaire: Heckman, $\mathrm{K}$ (Heckman study); Rebulla, P (IPTAS study \& Trigger study); Corash, L (Lozano study \& SPRINT study); Fletcher, D; Goodrich, R (MIRACLE study); Wandt H (Nuerenberg study); Corson, J; Slichter, S (PLADO study); McClelland, S; Powter, G; Stanworth, S (PPiP study \& TOPPs study); Kerkhoffs, JL; van de Watering, L (PrePAReS study \& TriPlate study); Barty, R; Heddle, N (SToP study); Tinmouth, A (Tinmouth study)

All authors who supplied CRFs: Zumberg, M (Zumberg study).

L. Corash for provision of unpublished material from SPRINT study.

Other members of the BEST Project group: Hervig, T; Lozano, M; Tinmouth, A; van de Watering, L; Williamson, L who provided input on the design of the study.

Ruth Strachan for her assistance with translating CRFs.

\section{Authorship}

Contribution: All authors contributed to the writing of the manuscript; L.J.E, N.H and S.J.S. designed the research; L.J.E collected, analyzed and interpreted the data; J.M., N.H., S.J.S, and S.S. provided study CRFs and completed the questionnaire.

Conflict of Interest: The authors declare that they have no conflicts of interest relevant to the manuscript submitted to Transfusion. Several authors are PIs on included trials.

A complete list of the members of the BEST Collaborative Project Group and the BEST Collaborative appears as a data supplement (Appendix 2) to the online version of this article.

Correspondence: Dr Lise J Estcourt, NHS Blood and Transplant, Level 2, John Radcliffe Hospital, Oxford, OX3 9BQ, United Kingdom; lise.estcourt@nhsbt.nhs.uk 
Funding This study was supported by the BEST Collaborative

Appendices 1 to 4: (Online only) 


\section{References}

1. Heckman KD, Weiner GJ, Davis CS, Strauss RG, Jones MP, Burns CP. Randomized study of prophylactic platelet transfusion threshold during induction therapy for adult acute leukemia: 10,000/microL versus 20,000/microL. J Clin Oncol 1997;15(3):1143-9.

2. Heddle N, Cook R, Tinmouth A, Kouroukis C, Hervig T, Klapper E, et al. A randomized controlled trial comparing standard and low dose strategies for transfusion of platelets (SToP) to patients with thrombocytopenia. Blood 2009;113(7):1564-73.

3. McCullough J. Therapeutic efficacy and safety of platelets treated with a photochemical process for pathogen inactivation: the SPRINT Trial. Blood 2004;104(5):1534-41.

4. Rebulla P, Finazzi G, Marangoni F, Avvisati G, Gugliotta L, Tognoni G, et al. The threshold for prophylactic platelet transfusions in adults with acute myeloid leukemia. Gruppo Italiano Malattie Ematologiche Maligne dell'Adulto. N Engl J Med 1997;337(26):1870-5.

5. Slichter SJ, Kaufman RM, Assmann SF, McCullough J, Triulzi DJ, Strauss RG, et al. Dose of prophylactic platelet transfusions and prevention of hemorrhage. N Engl J Med 2010;362(7):600-13.

6. Stanworth SJ, Dyer C, Choo L, Bakrania L, Copplestone A, Llewelyn C, et al. Do all patients with hematologic malignancies and severe thrombocytopenia need prophylactic platelet transfusions? Background, rationale, and design of a clinical trial (trial of platelet prophylaxis) to assess the effectiveness of prophylactic platelet transfusions. Transfus Med Rev 2010;24(3):16371.

7. Tinmouth A, Tannock IF, Crump M, Tomlinson G, Brandwein J, Minden M, et al. Low-dose prophylactic platelet transfusions in recipients of an autologous peripheral blood progenitor cell transplant and patients with acute leukemia: a randomized controlled trial with a sequential Bayesian design. Transfusion 2004;44(12):1711-9.

8. Wandt H, Wendelin K, Schaefer-Eckart K, Thalheimer R, Schubert MS, Conradi R, et al. A therapeutic platelet transfusion strategy without routine prophylactic transfusion is feasible and safe and reduces platelet transfusion numbers significantly: preliminary analysis of a randomized study in patients after high dose chemotherapy and autologous peripheral blood stem cell transplantation. Blood 2008;112 (ASH Annual Meeting Abstracts):Abstract 286.

9. Wandt H, Schaefer-Eckart K, Frank M, Birkmann J, Wilhelm M. A therapeutic platelet transfusion strategy is safe and feasible in patients after autologous peripheral blood stem cell transplantation. Bone Marrow Transplant 2006;37(4):387-92.

10. Sensebe L. The efficiency of transfusing high doses of platelets in hematologic patients with thrombocytopenia: results of a prospective, randomized, open, blinded end point (PROBE) study. Blood 2005;105(2):862-64.

11. Heddle NM, Wu C, Vassallo R, Carey P, Arnold D, Lozano M, et al. Adjudicating bleeding events in a platelet dose study: impact on outcome results and challenges. Transfusion 2011;51(11):2304-10.

12. Estcourt L, Stanworth SJ, Doree C, Hopewell S, Murphy MF, Tinmouth A, et al. Prophylactic platelet transfusion for the prevention of haemorrhage after chemotherapy and stem cell transplantation. Cochrane Database of Systematic Reviews 2012(5).

13. Delaney M, Meyer E, Cserti-Gazdewich C, Haspel RL, Lin Y, Morris A, et al. A systematic assessment of the quality of reporting for platelet transfusion studies. Transfusion 2010;50(10):2135-44.

14. Higby DJ, Cohen E, Holland JF, Sinks L. The prophylactic treatment of thrombocytopenic leukemic patients with platelets: a double blind study. Transfusion 1974;14(5):440-6.

15. Murphy S, Litwin S, Herring LM, Koch P, Remischovsky J, Donaldson MH, et al. Indications for platelet transfusion in children with acute leukaemia. Am J Hematol 1982;12(4):347-56.

16. Roy AJ, Jaffe N, Djerassi I. Prophylactic Platelet Transfusions in Children with Acute Leukaemia: A Dose Response Study. Transfusion 1973;13(5):283-90.

17. Solomon J, Bofenkamp T, Fahey JL, Chillar RK, Beutel E. Platelet prophylaxis in acute non-lymphoblastic leukaemia. Lancet 1978;8058:267.

18. Diedrich B, Remberger M, Shanwell A, Svahn BM, Ringden O. A prospective randomized trial of a prophylactic platelet transfusion trigger of $10 \times 10(9)$ per $L$ versus $30 \times 10(9)$ per $L$ in allogeneic hematopoietic progenitor cell transplant recipients. Transfusion 2005;45(7):1064-72.

19. Sintnicolaas K, van de Velden K, Sizoo W, Haije WG, Abels J, Lowenberg B. Comparison of 'prophylactic' and 'therapeutic' singledonor platelet transfusions in patients with acute leukaemia. Br J Haematol 1982;50:684-5.

20. Kerkhoffs JL, Eikenboom JC, Schipperus MS, van Wordragen-Vlaswinkel RJ, Brand R, Harvey MS, et al. A multicenter randomized study of the efficacy of transfusions with platelets stored in platelet additive solution II versus plasma. Blood 2006;108(9):3210-5.

21. Lozano M, Knutson F, Tardivel R, Cid J, Maymó RM, Löf H, et al. A multi-centre study of therapeutic efficacy and safety of platelet components treated with amotosalen and ultraviolet A pathogen inactivation stored for 6 or $7 \mathrm{~d}$ prior to transfusion. $\mathrm{Br} \mathrm{J}$ Haematol 2011;153(3):393-401. 
22. Zumberg MS, del Rosario ML, Nejame CF, Pollock BH, Garzarella L, Kao KJ, et al. A prospective randomized trial of prophylactic platelet transfusion and bleeding incidence in hematopoietic stem cell transplant recipients: $10,000 / \mu \mathrm{L} v e r s u s ~ 20,000 / \mu \mathrm{L}$ trigger. Biol Blood Marrow Transplant 2002;8(10):569-76.

23. Cazenave J-P, Follea G, Bardiaux L, Boiron J-M, Lafeuillade M, Debost M, et al. A randomized controlled clinical trial evaluating the performance and safety of platelets treated with MIRASOL pathogen reduction technology. Transfusion 2010;50(11):2362-75.

24. MacLennan S. Comparison of platelets stored for 2 - 5 versus 6 - 7 days in preventing and treating haemorrhage in thrombocytopenic patients: a randomised controlled trial ISRCTN, 2007.

25. Steffens I, Harrison JF, Taylor CPF. A dose response study of platelet transfusion: comparison between triple dose apheresis platelet transfusion and three split standard transfusions. Haematologica 2002;87(Supp 1):7th Congress of the European Hematology Association (EHA), Florence, Italy, June 2002.

26. Simonsen AC, Johansson PI, Conlan MG, Jacquet M, Lin JS, Junge K, et al. Transfusion of 7-day-old amotosalen photochemically treated buffy-coat platelets to patients with thrombocytopenia: a pilot study. Transfusion 2006;46(3):424-33.

27. van Rhenen D, Gulliksson H, Cazenave JP, Pamphilon D, Ljungman P, Kluter $H$, et al. Transfusion of pooled buffy coat platelet components prepared with photochemical pathogen inactivation treatment: the euroSPRITE trial. Blood 2003;101(6):242633.

28. Goodnough LT, Kuter DJ, McCullough J, Slichter SJ, DiPersio J, Romo J, et al. Prophylactic platelet transfusions from healthy apheresis platelet donors undergoing treatment with thrombopoietin. Blood 2001;98(5):1346-51.

29. Janetzko K, Cazenave JP, Kluter H, Kientz D, Michel M, Beris P, et al. Therapeutic efficacy and safety of photochemically treated apheresis platelets processed with an optimized integrated set. Transfusion 2005;45(9):1443-52.

30. Agliastro R, De Francisci G, Bonaccoroso R, Spicola D, Ziino O, Arico M, et al. Clinical study in pediatric hemato-oncology patients:efficacy of pathogen inactivated buffy coat platelets versus aphaeresis platelets. Transfusion 2006;46(9s):117A.

31. Bentley M, Taylor K, Wright S, Kelly C, Taylor D, Rodwell R. RH-thrombopoietin-derived autologous cryopreserved platelet support for PBPC transplantation. Blood 2000;96(11):425a.

32. Harrup RK, JT, Kiss J, Daniels B. Randomised blinded comparison of buffy coat plasma or T-sol supported platelet transfusions. Haematology Society of Australia and New Zealand Annual Scientific Meeting. Hobart; Tasmania 1999;Abstract.

33. Kerkhoffs JL, van Putten WL, Novotny VM, Te Boekhorst PA, Schipperus MR, Zwaginga JJ, et al. Clinical effectiveness of leucoreduced, pooled donor platelet concentrates, stored in plasma or additive solution with and without pathogen reduction. Br J Haematol 2010;150(2):209-17.

34. Brand A. Clinical effectiveness of standard versus pathogen-reduced buffy coat-derived platelet concentrates in plasma in acute myeloid leukemia patients. 13 Nov 2009 ed: Nederlands Trial Register, 2009:NTR 2106.

35. Arnold DM, Crowther MA, Cook RJ, Sigouin C, Heddle NM, Molnar L, et al. Utilization of platelet transfusions in the intensive care unit: indications, transfusion triggers, and platelet count responses. Transfusion 2006;46(8):1286-91.

36. Rebulla P, Grazzini G, Liumbruno G, Aprili G, Formisano S, Girelli G, et al. Pathogen inactivated platelets and prevention of immunological adverse reactions: The Italian Platelet Technology Assessment Study (IPTAS), 2009. http://www.bloodtransfusion.it/articoli/47/en/Doi\%200013.pdf. [Accessed 21st November 2011].

37. Kumar V, Abbas AK, Aster J. Robbins \& Cotran Pathologic Basis of Disease. 8th ed. Philadelphia: Saunders, 2009.

38. Burns T, Breathnach S, Cox N, Griffiths C, editors. Rook's Textbook of Dermatology. Oxford: Wiley-Blackwell, 2010.

39. WHO. WHO Handbook for Reporting Results of Cancer Treatment. 48 ed. Geneva: World Health Organisation, 1979.

40. Ajani J, Welsh S, Raber M. Comprehensive criteria for assessing therapy-induced toxicity. Cancer Invest 1990;8:141-53.

41. Snyder E, McCullough J, Slichter SJ, Strauss RG, Lopez-Plaza I, Lin JS, et al. Clinical safety of platelets photochemically treated with amotosalen $\mathrm{HCl}$ and ultraviolet A light for pathogen inactivation: the SPRINT trial. Transfusion 2005;45(12):1864-75.

42. Simpson E, Lin Y, Stanworth S, Birchall J, Doree C, Hyde C. Recombinant factor VIla for the prevention and treatment of bleeding in patients without haemophilia. Cochrane Database of Systematic Reviews 2012(3).

43. Corash L, Lin JS, Sherman CD, Eiden J. Determination of acute lung injury after repeated platelet transfusions. Blood 2011;117(3):1014-20.

44. Stanworth SJ, Dyer C, Casbard A, Murphy MF. Feasibility and usefulness of self-assessment of bleeding in patients with haematological malignancies, and the association between platelet count and bleeding. Vox Sang 2006;91(1):63-9.

45. Webert KE, Arnold DM, Lui Y, Carruthers J, Arnold E, Heddle NM. A new tool to assess bleeding severity in patients with chemotherapy-induced thrombocytopenia. Transfusion 2012. On-line publication ahead of print.

46. Heddle NM, Arnold DM, Webert KE. Time to rethink clinically important outcomes in platelet transfusion trials. Transfusion 2011;51(2):430-34. 


\section{List of Tables}

Table 1. Baseline characteristics of included studies

Table 2. Bleeding rates

Table 3. Site and severity of bleeding documented

Table 4. Procedures/interventions

Table 5. Comparison of CTCAE and WHO grades (Data from SPRINT5 Trial - including previously unpublished data)

Table 6. Suggestions to increase consistency in future studies that use bleeding as a primary outcome measure

\section{List of Figures}

Figure 1. Flow diagram for identification of authors 
Figure 1. Flow Diagram for identification of authors

Records identified from updated Cochrane Systematic Review of Prophylactic Platelet Transfusions ${ }^{12}$

Full Text Articles $(n=178)$

Records identified from BEST

Collaborative $^{13}$

Full Text Articles

$(n=47)$

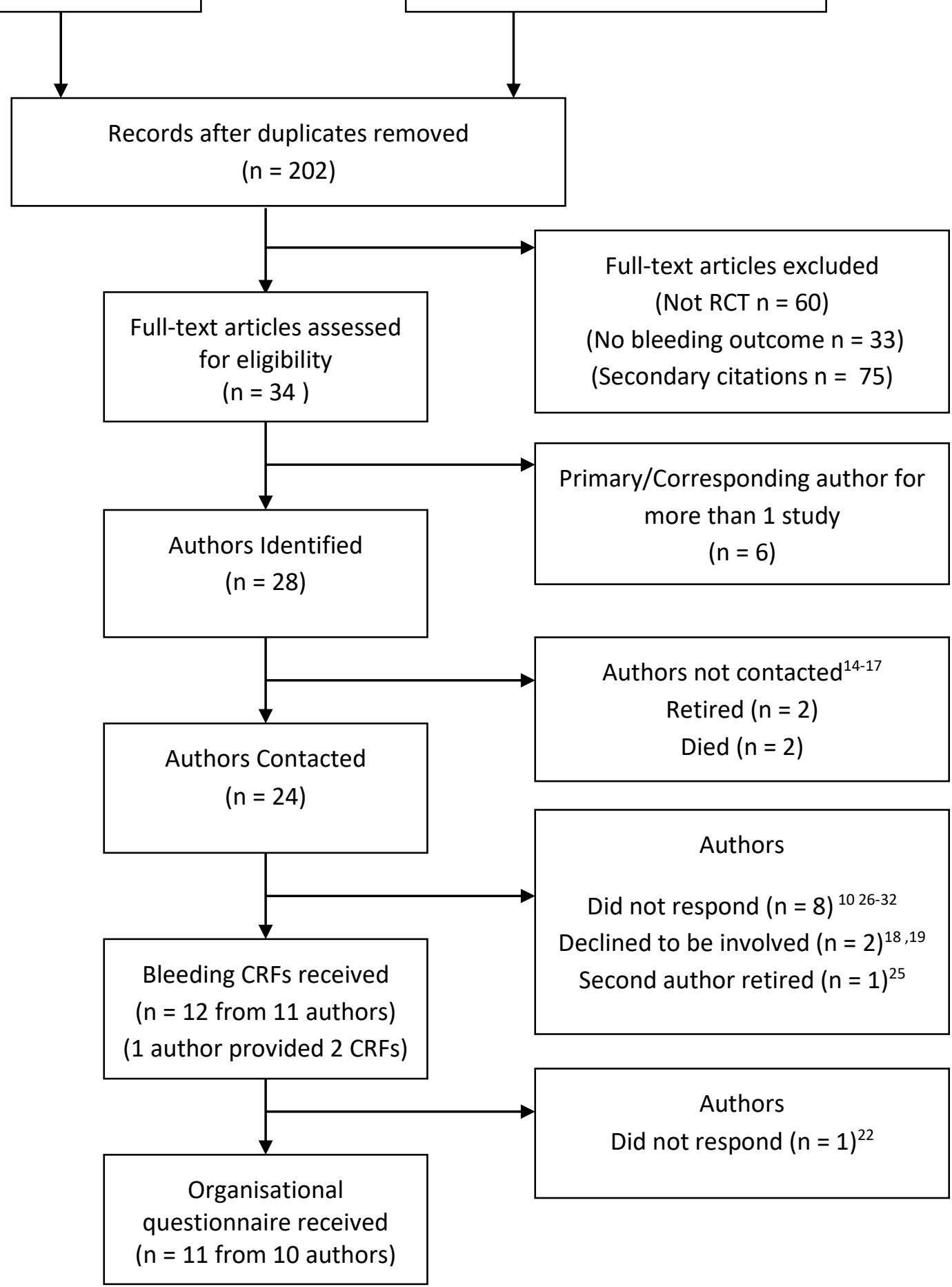


Table 1. Baseline characteristics of included studies

\begin{tabular}{|c|c|c|c|c|c|c|c|c|c|}
\hline $\begin{array}{l}\text { Authors who } \\
\text { provided } \\
\text { data }\end{array}$ & Study & Type of study & $\begin{array}{l}\text { Study } \\
\text { period }\end{array}$ & Country & $\begin{array}{l}\text { Number of } \\
\text { participants } \\
\text { randomized }\end{array}$ & Intervention & $\begin{array}{l}\text { CRF } \\
\text { Sent }\end{array}$ & $\begin{array}{l}\text { Questionnaire } \\
\text { returned }\end{array}$ & $\begin{array}{l}\text { Study } \\
\text { results } \\
\text { published }\end{array}$ \\
\hline \multicolumn{10}{|c|}{ Platelet Threshold Studies } \\
\hline Heckman & Heckman et al $1997^{1}$ & Single centre Parallel RCT & $\begin{array}{l}\text { Apr } 1991 \text { to } \\
\text { Nov } 1995\end{array}$ & USA & 82 & $\begin{array}{l}\text { Prophylactic platelet transfusions } \\
\text { with different transfusion triggers }\end{array}$ & $\mathrm{Y}$ & $\mathrm{Y}$ & Y \\
\hline Rebulla & Trigger $^{4}$ & Multicentre Parallel RCT & $\begin{array}{l}\text { Mar } 1994 \text { to } \\
\text { Mar } 1997\end{array}$ & Italy & 276 & $\begin{array}{l}\text { Prophylactic platelet transfusions } \\
\text { with different transfusion triggers }\end{array}$ & $\mathrm{N}$ & $\mathrm{Y}$ & Y \\
\hline Zumberg & Zumberg et al $2001^{22}$ & Single centre Parallel RCT & $\begin{array}{l}\text { Jul } 1997 \text { to } \\
\text { Dec } 1999\end{array}$ & USA & 159 & $\begin{array}{l}\text { Prophylactic platelet transfusions } \\
\text { with different transfusion triggers }\end{array}$ & $\mathrm{Y}$ & $\mathrm{N}$ & Y \\
\hline \multicolumn{10}{|c|}{ Platelet Dose Studies } \\
\hline Heddle & SToP2 & Multicentre Parallel RCT & $\begin{array}{l}\text { Oct } 2003 \text { to } \\
\text { Jun } 2007\end{array}$ & $\begin{array}{c}\text { Canada, } \\
\text { Norway \& USA }\end{array}$ & 129 & $\begin{array}{l}\text { Low dose versus standard dose } \\
\text { platelet transfusions }\end{array}$ & Y & $\mathrm{Y}$ & Y \\
\hline Slichter & PLADO $^{5}$ & Multicentre Parallel RCT & $\begin{array}{l}\text { Jul } 2004 \text { to } \\
\text { Dec } 2007\end{array}$ & USA & 1351 & $\begin{array}{l}\text { Low dose versus standard dose } \\
\text { versus high dose platelet transfusions }\end{array}$ & $\mathrm{Y}$ & $\mathrm{Y}$ & Y \\
\hline Tinmouth & Tinmouth et al $2004^{7}$ & $\begin{array}{l}\text { Single centre Bayesian } \\
\text { approach study }\end{array}$ & $\begin{array}{l}\text { Feb } 2001 \text { to } \\
\text { Mar } 2002\end{array}$ & Canada & 111 & $\begin{array}{l}\text { Low dose versus standard dose } \\
\text { platelet transfusions }\end{array}$ & $\mathrm{Y}$ & Y & Y \\
\hline \multicolumn{10}{|c|}{ Pathogen reduced platelet component studies } \\
\hline Corash/ & SPRINT ${ }^{3 *+}$ & Multicentre Parallel RCT & $\begin{array}{l}\text { Jul } 1999 \text { to } \\
\text { Feb } 2001\end{array}$ & USA & 671 & $\begin{array}{l}\text { Pathogen reduced platelets versus } \\
\text { standard apheresis components }\end{array}$ & $\mathrm{Y}$ & Y & $Y$ \\
\hline
\end{tabular}




\begin{tabular}{|c|c|c|c|c|c|c|c|c|c|}
\hline McCullough & Lozano et al $2011^{21^{*+}}$ & Multicentre Parallel RCT & $\begin{array}{l}\text { Oct } 2005 \text { to } \\
\text { Jul } 2009\end{array}$ & $\begin{array}{l}\text { France, Spain, } \\
\text { Sweden \& UK }\end{array}$ & 242 & $\begin{array}{l}\text { Pathogen reduced platelets versus } \\
\text { standard platelet components }\end{array}$ & NA & NA & $\mathrm{Y}$ \\
\hline Goodrich & MIRACLE $23 \ddagger$ & Multicentre Parallel RCT & $\begin{array}{l}\text { Dec } 2005 \text { to } \\
\text { Sep } 2007\end{array}$ & France & 118 & $\begin{array}{l}\text { Pathogen reduced platelets versus } \\
\text { standard platelet components }\end{array}$ & Y & Y & $\mathrm{Y}$ \\
\hline \multirow{2}{*}{ Kerkhoffs } & TriPlate $33^{\dagger}$ & Multicentre Parallel RCT & $\begin{array}{l}\text { Mar } 2007 \text { to } \\
\text { Jan } 2009\end{array}$ & Netherlands & 295 & $\begin{array}{l}\text { Pathogen reduced platelets versus } \\
\text { standard platelet components }\end{array}$ & Y & Y & $Y$ \\
\hline & PrePAReS $^{34+}$ & Multicentre Parallel RCT & $\begin{array}{l}\text { Started Nov } \\
2010\end{array}$ & Netherlands & In progress & $\begin{array}{l}\text { Pathogen reduced platelets versus } \\
\text { standard platelet components }\end{array}$ & Y & $Y$ & $N$ \\
\hline Rebulla & IPTAS $^{36+\neq}$ & Multicentre Parallel RCT & $\begin{array}{l}\text { Started Dec } \\
2008\end{array}$ & Italy & In progress & $\begin{array}{l}\text { Pathogen reduced platelets versus } \\
\text { standard platelet components }\end{array}$ & Y & N & $\mathrm{N}$ \\
\hline \multicolumn{10}{|c|}{ Platelet age studies } \\
\hline \multicolumn{10}{|c|}{ Therapeutic only versus prophylactic platelet transfusions } \\
\hline Stanworth & TOPPs $^{6}$ & Multicentre Parallel RCT & $\begin{array}{l}2006 \text { to Aug } \\
2011\end{array}$ & Australia \& UK & 600 & $\begin{array}{l}\text { Prophylactic versus therapeutic only } \\
\text { platelet transfusions }\end{array}$ & Y & Y & $\mathrm{N}$ \\
\hline Wandt & Nuerenberg trial 89 & Parallel RCT & 2006 to 2010 & Germany & 400 & $\begin{array}{l}\text { Prophylactic versus therapeutic only } \\
\text { platelet transfusions }\end{array}$ & Y & Y & $\mathrm{N}$ \\
\hline
\end{tabular}

Parallel RCT = patients are randomized to intervention or control.

Crossover RCT = patients receive both the intervention and the control. Randomized to which one they receive first.

Bayesian approach study = differs from the standard frequentist approach to analysis. It starts with the researchers' a priori belief about the risk ratio and uses the study data to modify that opinion.

* Study has the same methodology as the SPRINT study on which CRFs and questionnaire were returned

tCerus pathogen-reduced platelet components (UVA in presence of amotosalen, S-59, in Intercept Blood System)

\#Caridian pathogen-reduced platelet components (UVA in presence of riboflavin, B2 in Mirasol Pathogen Reduction Technology)

$\S$ Study has the same methodology as the TOPPs study ${ }^{12}$ on which CRFs and questionnaire were returned

$\mathrm{RCT}=$ randomized controlled trial; $\mathrm{N}=\mathrm{No} ; \mathrm{NK}=$ not known; $\mathrm{NA}=$ not applicable; $\mathrm{Y}=$ Yes. 
Table 2. Bleeding rates

\begin{tabular}{|c|c|c|c|c|c|}
\hline First authors & Intervention & $\begin{array}{c}\text { Number of } \\
\text { patients in each } \\
\text { arm }\end{array}$ & $\begin{array}{l}\text { Percentage of patients } \\
\text { with any bleeding }\end{array}$ & $\begin{array}{l}\text { Percentage of patients with significant } \\
\text { bleeding/ WHO grade } 2 \text { or above }\end{array}$ & $\begin{array}{l}\text { Percentage of patients } \\
\text { with WHO grade } 3 \text { or } 4 \\
\text { bleeding or its equivalent }\end{array}$ \\
\hline \multicolumn{6}{|c|}{ Platelet threshold studies } \\
\hline \multirow{2}{*}{ Diedrich $2005^{18}$} & $<10 \times 10^{9} / I$ & 79 & - & 17.7 & 3.8 \\
\hline & $<30 \times 10^{9} / 1$ & 87 & - & 14.9 & 6.9 \\
\hline \multirow{2}{*}{ Rebulla $1997^{4}$} & $<10 \times 10^{9} / 1$ & 135 & - & 21.4 & $11.1^{*}$ \\
\hline & $<20 \times 10^{9} / 1$ & 120 & - & 20.0 & $9.2^{*}$ \\
\hline \multirow{2}{*}{ Heckman $1997^{1}$} & $<10 \times 10^{9} / \mathrm{I}$ & 37 & 94.6 & 45.9 & $-*$ \\
\hline & $<20 \times 10^{9} / 1$ & 41 & 90.2 & 17.1 & $-*$ \\
\hline \multirow{2}{*}{ Zumberg $2002^{22}$} & $<10 \times 10^{9} / 1$ & 78 & 94.9 & 26.9 & $-*$ \\
\hline & $<20 \times 10^{9} / /$ & 81 & 97.5 & 25.9 & $-*$ \\
\hline \multicolumn{6}{|c|}{ Platelet dose studies } \\
\hline \multirow{2}{*}{ Sensebe $2004^{10}$} & Standard dose & 48 & 18.8 & 4.2 & - \\
\hline & High dose & 48 & 10.4 & 6.3 & - \\
\hline \multirow{2}{*}{ Tinmouth $2004^{7}$} & Low dose & 56 & - & 10.7 & $-*$ \\
\hline & Standard dose & 55 & - & 7.3 & $-*$ \\
\hline \multirow{2}{*}{ Heddle $2009^{2}$} & Low dose & 58 & 91.4 & 51.7 & 13.8 \\
\hline & Standard dose & 61 & 78.7 & 49.2 & 9.8 \\
\hline \multirow{2}{*}{ Slichter $2010^{5}$} & Low dose & 417 & - & 71.0 & 12.0 \\
\hline & Standard dose & 423 & - & 69.0 & 9.0 \\
\hline
\end{tabular}




\begin{tabular}{|c|c|c|c|c|c|}
\hline & High dose & 432 & - & 69.9 & 10.0 \\
\hline \multicolumn{6}{|c|}{ Pathogen reduced platelet studies } \\
\hline \multirow{2}{*}{ Janetzko $2005^{29}$} & $p-R x ;$ apheresis & 22 & 63.6 & - & - \\
\hline & Standard apheresis & 21 & 71.4 & - & - \\
\hline \multirow{3}{*}{ Kerkhoffs $2010^{33}$} & $p$-Rx; PAS III; BC & 85 & 31.8 & 12.9 & $5.9^{*}$ \\
\hline & PAS III; BC & 94 & 14.9 & 4.3 & $0^{*}$ \\
\hline & Plasma; BC & 99 & 19.2 & 7.1 & $1.0^{*}$ \\
\hline \multirow{2}{*}{ McCullough $2004^{3}$} & $\mathrm{p}-\mathrm{Rx}$; apheresis & 318 & 89.6 & - & 4.1 \\
\hline & Standard apheresis & 327 & 84.7 & - & 6.1 \\
\hline
\end{tabular}

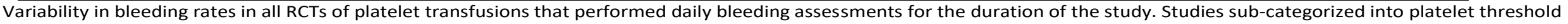

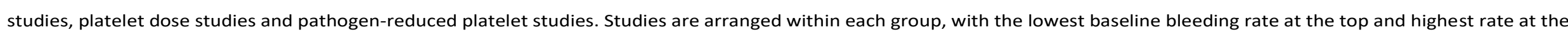
bottom. Authors from the studies ${ }^{10} 1829$ in italics did not participate in this study.

$\mathrm{p}-\mathrm{Rx}=$ pathogen reduced platelet components

PAS III = platelet additive solution III

$\mathrm{BC}=$ buffy coat

* Study did not use the WHO grading system 
Table 3. Site and severity of bleeding documented

Documented in the 12 case report forms (CRFs)

*The denominator is the number of CRFs that reported bleeding at that anatomical site

\begin{tabular}{|c|c|c|c|c|c|c|}
\hline $\begin{array}{l}\text { Site of bleeding } \\
\text { Documented on CRF }\end{array}$ & No. of CRFs & $\begin{array}{l}\text { Specific types of } \\
\text { bleed at each }\end{array}$ & No. of CRFs* & \multicolumn{2}{|c|}{$\begin{array}{l}\text { Severity of bleeding documented on CRFs that documented } \\
\text { bleeding at an anatomical site }\end{array}$} & No. of CRFs* \\
\hline \multirow{2}{*}{ Mouth } & \multirow{2}{*}{$12 / 12$} & \multirow{2}{*}{-} & \multirow{2}{*}{$12 / 12$} & \multirow{2}{*}{ Mouth } & Duration & $9 / 12$ \\
\hline & & & & & Intervention & $3 / 12$ \\
\hline \multirow{3}{*}{ GI } & \multirow{3}{*}{$12 / 12$} & Melena & $12 / 12$ & \multirow{3}{*}{ GI } & $\begin{array}{l}\text { Number of separate bleeding } \\
\text { occasions }\end{array}$ & $2 / 12$ \\
\hline & & Hematemesis & $12 / 12$ & & & \\
\hline & & Hematochezia & & & Intervention & $3 / 12$ \\
\hline \multirow{2}{*}{ CNS } & \multirow{2}{*}{$11 / 12$} & \multirow[b]{2}{*}{-} & \multirow{2}{*}{$11 / 11$} & \multirow{2}{*}{ CNS } & Neurological symptoms/signs & $10 / 11$ \\
\hline & & & & & Intervention & $3 / 11$ \\
\hline \multirow{3}{*}{ Urogenital } & \multirow{3}{*}{$11 / 12$} & Hematuria & $11 / 11$ & \multirow{3}{*}{ Urogenital } & Severity of hematuria & $9 / 11$ \\
\hline & & Vaginal & \multirow{2}{*}{$10 / 11$} & & Severity of vaginal bleeding & $9 / 11$ \\
\hline & & & & & Intervention & $3 / 11$ \\
\hline \multirow[b]{2}{*}{ Nose } & \multirow[b]{2}{*}{$11 / 12$} & \multirow[b]{2}{*}{-} & \multirow[b]{2}{*}{$11 / 11$} & \multirow[b]{2}{*}{ Nose } & Duration & $9 / 11$ \\
\hline & & & & & Intervention & $3 / 11$ \\
\hline \multirow{3}{*}{ Eye } & \multirow{3}{*}{$10 / 12$} & Retinal & $10 / 10$ & \multirow{3}{*}{ Eye } & Visual impairment & $9 / 10$ \\
\hline & & Conjunctival & $3 / 10$ & & \multirow[b]{2}{*}{ Ophthalmology review } & \multirow[b]{2}{*}{$3 / 10$} \\
\hline & & Vitreous & $1 / 10$ & & & \\
\hline
\end{tabular}




\begin{tabular}{|c|c|c|c|c|c|c|}
\hline $\begin{array}{l}\text { Pulmonary } \\
\text { (Hemoptysis) }\end{array}$ & $10 / 12$ & - & $10 / 10$ & Pulmonary (Hemoptysis) & Intervention & $4 / 10$ \\
\hline \multirow{3}{*}{ Skin } & \multirow{3}{*}{$10 / 12$} & Petechiae & $9 / 10$ & \multirow{3}{*}{ Skin } & Spread & $5 / 10$ \\
\hline & & Purpura & $8 / 10$ & & Size & $8 / 10$ \\
\hline & & Ecchymoses & $4 / 10$ & & Number & $4 / 10$ \\
\hline Insertion site & $9 / 12$ & - & $9 / 9$ & Insertion site & - & - \\
\hline \multirow{2}{*}{ Musculo-skeletal } & \multirow[b]{2}{*}{$8 / 12$} & Hematoma & $8 / 8$ & \multirow{2}{*}{ Musculo-skeletal } & \multirow[b]{2}{*}{ - } & \multirow[b]{2}{*}{ - } \\
\hline & & Joint bleed & $3 / 8$ & & & \\
\hline \multirow{2}{*}{ Body cavities } & \multirow{2}{*}{$5 / 12$} & \multirow[b]{2}{*}{-} & \multirow{2}{*}{$5 / 5$} & \multirow{2}{*}{ Body cavities } & Severity of bleeding & $5 / 5$ \\
\hline & & & & & Intervention & $2 / 5$ \\
\hline Associated with surgery & $4 / 12$ & - & $4 / 4$ & Associated with surgery & - & - \\
\hline Other (please specify) & $7 / 12$ & - & $7 / 7$ & Other (please specify) & - & - \\
\hline
\end{tabular}


Table 4. Procedures/interventions

\begin{tabular}{|c|c|c|c|}
\hline Procedure/Intervention/Transfusion & No. of CRFs* & $\begin{array}{l}\text { Sub-categorization of } \\
\text { procedure/Intervention/Transfusion }\end{array}$ & No. of CRFs* \\
\hline Any & $10 / 12$ & - & - \\
\hline \multirow{2}{*}{ Endoscopy } & \multirow[b]{2}{*}{$3 / 12$} & Colonoscopy & $2 / 3$ \\
\hline & & Bronchoscopy & $2 / 3$ \\
\hline Bladder irrigation & $2 / 12$ & - & - \\
\hline \multirow{2}{*}{ Nasal } & \multirow{2}{*}{$1 / 12$} & Packing & $1 / 1$ \\
\hline & & Cauterization & $1 / 1$ \\
\hline Pericardiocentesis & $1 / 12$ & - & - \\
\hline \multirow[b]{2}{*}{ Transfusion } & \multirow[b]{2}{*}{$10 / 12$} & RBCs & $10 / 10$ \\
\hline & & FFP & $3 / 10$ \\
\hline Factor concentrates & $3 / 12$ & Factor VIla & $2 / 3$ \\
\hline \multirow{3}{*}{ Medications } & \multirow{3}{*}{$2 / 12$} & Tranexamic acid & $2 / 2$ \\
\hline & & DDAVP & $2 / 2$ \\
\hline & & Aminocaproic acid & $2 / 2$ \\
\hline Topical fibrin glue & $1 / 12$ & - & - \\
\hline
\end{tabular}

Documented in the 12 case report forms (CRFs)

*The denominator is the number of CRFs that reported a particular intervention/procedure or transfusion 
Table 5. Comparison of CTCAE and WHO grades (Data from SPRINT ${ }^{3}$ Trial - including previously unpublished data)

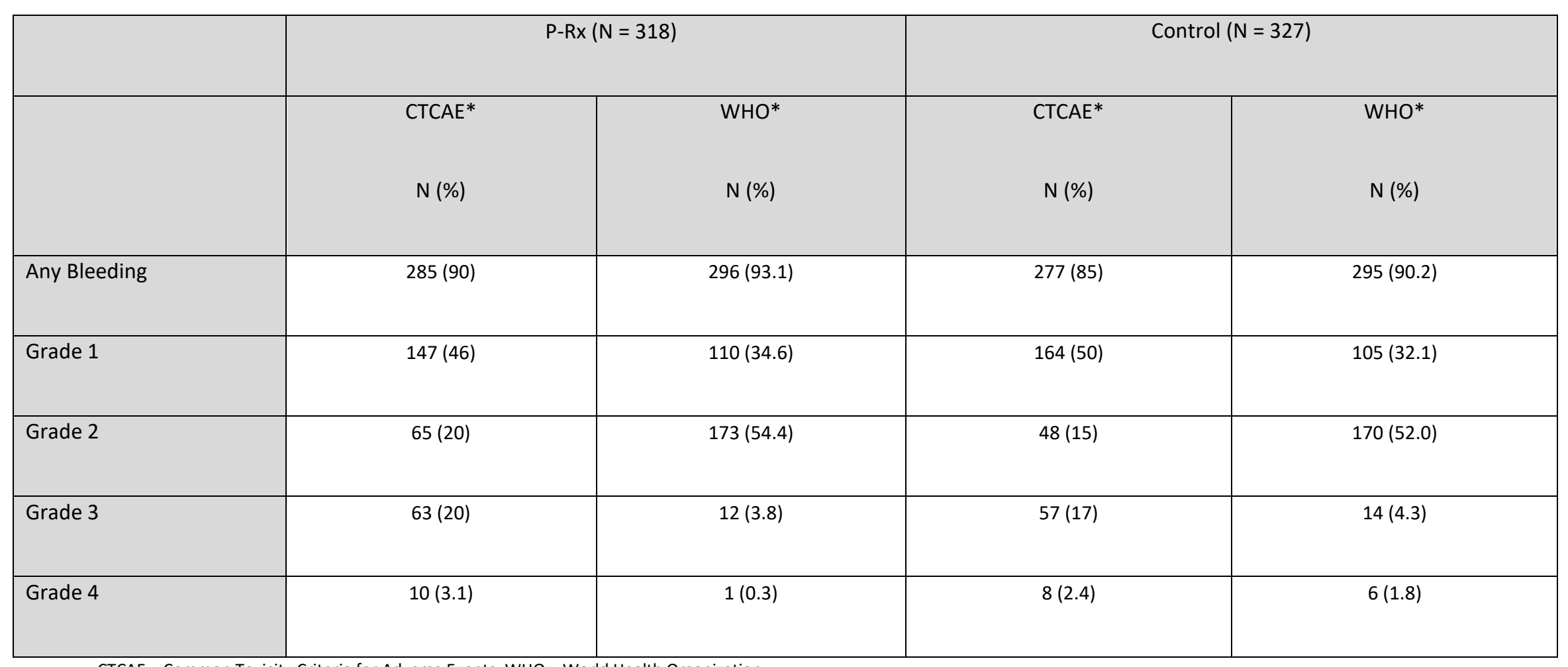

CTCAE = Common Toxicity Criteria for Adverse Events; WHO = World Health Organization

* Maximum bleeding grade the patient experienced during the study 
Table 6. Suggestions to increase consistency in future studies that use bleeding as a primary outcome measure

1.

Studies should use methods to minimize inter-observer variability of bleeding

assessors

Methods of doing this will vary depending on study resources but could include:

- Training of staff prior to and during study

- Dual bleeding assessments and feedback

- Dummy bleeding scenarios

2. Develop international consensus on a minimum data set required if bleeding is to be used as the primary outcome of the study

- In the future standard case report forms could be developed

3. Develop consistency in the way bleeding is reported so that studies can be compared

4. If a particular grading system is used, international agreement is required on the criteria to allocate bleeding to a specific grade

5. If skin bleeding is to be categorized, need international agreement on definitions for petechiae, purpura, ecchymoses and hematomas 


\section{Appendix 1: Search Strategy for identification of authors}

\section{Search Strategy for the Cochrane Review ${ }^{12}$}

The search was not limited by language or publication date

1 MEDLINE search strategy (1996 to Jan 2002)

1. Platelet Transfusion.mh.

2. platelet $\$$ adj10 (substitute $\$$ or transfusion $\$$ or prophyla $\$$ ).tw.

3. 1 or 2

4. haemorrhage.mh.

5. platelet\$.tw.

6. 4 and 5

7. exp Blood Transfusion/

8. 5 and 7

9. 3 or 6 or 8

10. randomised controlled trial.pt.

11. controlled clinical trial.pt.

12. randomised controlled trials/

13. random allocation/

14. double blind method/

15. single blind method/

16. clinical trial.pt.

17. exp clinical trials/

18. (clinic $\$$ adj25 trial\$).ti, ab.

19. cross-over studies/

20. (crossover or cross-over or cross over).tw.

21. ((singl $\$$ or doubl\$ or trebl $\$$ or tripl $\$$ ) adj25 (blind $\$$ or mask $\$)$ ).ti, ab.

22. placebos/

23. placebo $\$ . t i, a b$.

24. random $\$ . t i, a b$.

25. research design/

26. or $/ 10-25$

27. 9 and 26

28. animal/ not (animal/ and human/)

29. 27 not 28

2 MEDLINE (Ovid) search strategy (Jan 2002-March 2011)

1. BLOOD PLATELETS/

2. platelet $^{\star}$ or thrombocyte $\left.{ }^{\star}\right)$.tw.

3. 1 or 2

4. $\exp$ BLOOD TRANSFUSION/

5. transfus*.tw.

6. 4 or 5

7. 3 and 6

8. PLATELET TRANSFUSION/

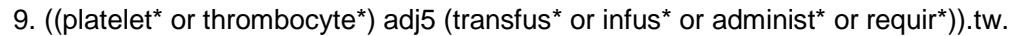

10. or/7-9

11. (prophylactic ${ }^{*}$ or prophylax* or prevent*).tw.

12. 10 and 11

13. RANDOMIZED CONTROLLED TRIAL.pt.

14. CONTROLLED CLINICAL TRIAL.pt.

15. exp CLINICAL TRIAL/

16. MULTICENTER STUDY.pt.

17. CLINICAL TRIALS AS TOPIC/

18. CLINICAL TRIALS PHASE III AS TOPIC/

19. CLINICAL TRIALS PHASE IV AS TOPIC/

20. $\exp$ CONTROLLED CLINICAL TRIALS AS TOPIC/

21. RANDOM ALLOCATION/

22. DOUBLE BLIND METHOD/

23. SINGLE BLIND METHOD/

24. CROSSOVER STUDIES/

25. PLACEBOS/

26. or/13-25

27. (controlled adj3 (trial ${ }^{\star}$ or stud $\left.\left.{ }^{\star}\right)\right) . t i, a b$.

28. (blind ${ }^{*}$ or mask $\left.{ }^{*}\right)$.ti,ab.

29. (placebo* or random* or factorial $\left.{ }^{\star}\right) . t i, a b$.

30. (crossover or (cross adj over)).ti,ab.

31. aleatori ${ }^{\star} . t, a b$.

32. (treatment adj arm*).ti,ab.

33. ((phase adj iii) or (phase adj three) or (phase adj ' 3 ')).ti,ab.

34. (latin adj square).ti,ab.

35. or/27-34

36. 26 or 35 
3 EMBASE (Ovid) search strategy (1980 to Jan 2002)

1. random $\$ . t i, a b$.

2. factorial\$.ti, ab.

3. (crossover\$ or crossover $\$$ or crossover $\$$ ).ti, ab.

4. placebo\$.ti,ab.

5. (double $\$$ adj blind $\$$ ).ti, ab.

6. (singl\$ adj blind $\$$ ).ti,ab.

7. assign $\$ . t i, a b$.

8. allocat\$.ti,ab.

9. volunteer\$.ti,ab.

10. CROSSOVER PROCEDURE.sh.

11. DOUBLE-BLIND PROCEDURE.sh.

12. RANDOMIZED CONTROLLED TRIAL.sh.

13. SINGLE-BLIND PROCEDURE.sh

14. versus.ti,ab,sh.

15. factorial.ti,ab.

16. latin square design.sh.

17. latine square.mp.

18. aleatoric.ab.

19. aleatory.ti,ab.

20. aleatorized.ab.

21. aleatorily.ab.

22. multicenter.ti,ab.

23. multicenter study.sh.

24. multicentered.ti,ab.

25. multicenters.ti,ab.

26. multicenterstudy.ti,ab.

27. multicenterstudie.ti.

28. multicenterstudies.ab.

29. multicentre.ti,ab.

30. multicentred.ti,ab.

31. multicentral.ti,ab.

32. multicentres.ti,ab.

33. or/1-32

34. ANIMAL/or NONHUMAN/ or ANIMAL EXPERIMENT

35. HUMAN

36. 35 and 34

37. 34 not 36

38. 33 not 37

39. THROMBOCYTE TRANSFUSION/

40. 38 and 39

4 EMBASE (Ovid) search strategy (Jan 2002-March 2011)

1. THROMBOCYTE/

2. ( platelet $^{\star}$ or thrombocyte $\left.{ }^{\star}\right)$.tw.

3. 1 or 2

4. $\exp$ BLOOD TRANSFUSION/

5. transfus*.tw.

6. 4 or 5

7. 3 and 6

8. THROMBOCYTE TRANSFUSION/

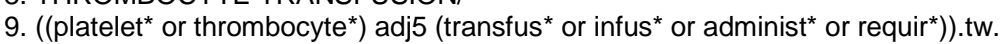

10. or/7-9

11. (prophylactic* or prophylax ${ }^{*}$ or prevent $\left.{ }^{\star}\right) . t w$.

12. 10 and 11

11. random* ${ }^{*}$ ti,ab.

12. factorial ${ }^{*} . \mathrm{ti}, \mathrm{ab}$

13. (crossover ${ }^{\star}$ OR cross over ${ }^{\star}$ OR cross-over $\left.{ }^{\star}\right) \cdot \mathrm{ti}, \mathrm{ab}$

14. placebo*.ti,ab.

15. (double* adj blind $\left.{ }^{\star}\right)$.ti,ab.

16. (singl* adj blind*).ti,ab.

17. assign $^{\star}$ or allocat $\left.{ }^{\star}\right) . t i, a b$.

18. (latin square or aleator $\left.{ }^{\star}\right)$.ti.ab.

19. volunteer*.ti,ab.

20. CROSSOVER PROCEDURE/

21. DOUBLE BLIND PROCEDURE/

22. RANDOMIZED CONTROLLED TRIAL/

23. SINGLE BLIND PROCEDURE/

24. or/11-23

25. $\exp$ ANIMAL/ OR NONHUMAN/ OR $\exp$ ANIMAL EXPERIMENT/

26. $\exp$ HUMAN/

27. 25 NOT 26 
5 CENTRAL search strategy (Issue 2, 2011)

\#1 MeSH descriptor Blood Platelets explode all trees

\#2 platelet $^{\star}$ or thrombocyte ${ }^{*}$

\#3 (\#1 OR \#2)

\#4 MeSH descriptor Blood Transfusion explode all trees

\#5 transfus*

\#6 (\#4 OR \#5)

\#7 (\#3 AND \#6)

\#8 MeSH descriptor Platelet Transfusion explode all trees

\#9 (platelet ${ }^{\star}$ or thrombocyte ${ }^{\star}$ ) NEAR/5 (transfus* or infus* ${ }^{*}$ or administ* or requir $^{*}$ )

\#10 (\#7 OR \#8 OR \#9)

\#11 prophylactic* or prophylax* or prevent ${ }^{\star}$

\#12 (\#10 AND \#11)

6 CINAHL (NHS Evidence) search strategy (Jan 2002-March 2011)

1. BLOOD PLATELETS/

2. platelet $^{\star}$ or thrombocyte $\left.{ }^{\star}\right) \cdot \mathrm{ti}, \mathrm{ab}$

3. 1 or 2

4. exp BLOOD TRANSFUSION/

5. transfus*.ti,ab

6. 4 or 5

7. 3 and 6

8. PLATELET TRANSFUSION/

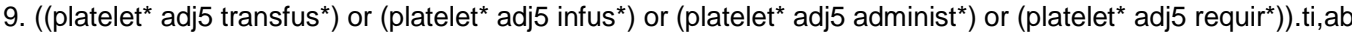

10. ((thrombocyte ${ }^{*}$ adj5 transfus ${ }^{*}$ ) or (thrombocyte* adj5 infus*) or (thrombocyte* adj5 administ ${ }^{\star}$ ) or (thrombocyte* adj5 requir $\left.{ }^{*}\right)$ ).ti,ab

11.7 or 8 or 9 or 10

12. (prophylactic* or prophylax* or prevent*).ti,ab

13. 11 and 12

14. "CLINICAL TRIAL"/

15. ((controlled adj trial* ${ }^{*}$ OR (clinical adj trial*)).ti,ab

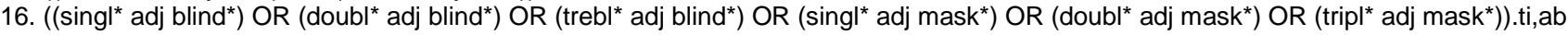
randomi*.ti,ab

17. RANDOM ASSIGNMENT/

18. ("phase III" OR "phase 3" OR "phase three").ti,ab

19. (random* adj1 allocat*).ti,ab

20. (random* adj1 assign $\left.{ }^{*}\right) . t i, a b$

21. PLACEBOS

22. 14 OR 15 OR 16 OR 17 OR 18 OR 19 OR 20 OR 21

23. 13 AND 22

7 Free text search strategy for other databases

(platelet* OR thrombocyte*) AND (transfus* OR infus* OR administ* OR requir*) AND (prophylactic* OR prophylaxis OR prevent

OR prevention OR preventing)

\section{Search Strategy for the BEST Review ${ }^{13}$}

MEDLINE (1996-October 2008) using "platelet transfusion" as the key search term.

The search was limited to those published in the English language, involving humans, and to core clinical journals.

There was consensus to include additional journals with specific relevance to transfusion medicine that were not included in the core clinical journals by MEDLINE. Clinically relevant journals added because of specific relevance to trnasfusion medicine: Transfusion, Transfusion Medicine, Vox Sanguinis, British Journal of Haematology, Blood, Journal of American Medical Association, New England Journal of Medicine, Lancet, Circulation, Critical Care Medicine, Journal of Thrombosis and Haemostasis, and Bone Marrow Transplantation. 


\section{Appendix 2: Organisational Form for Bleeding Assessment}

Study Name.

Date of study.

Bleeding Assessments (i.e. method of collecting data by bedside or from patient notes)

\begin{tabular}{|c|c|c|c|}
\hline \multirow[t]{6}{*}{ a) } & How was bleeding assessed? & & \\
\hline & From Patient Notes/Chart & YES & NO \\
\hline & By formalized bleeding assessment & YES & NO \\
\hline & Examination of patient & YES & NO \\
\hline & Patient questionnaire & YES & NO \\
\hline & Nurse questionnaire & YES & NO \\
\hline b) & How frequently was bleeding assessed? (e.g. 8 hourly; daily, etc.) & & \\
\hline \multirow[t]{2}{*}{ c) } & Was the bleeding assessment performed at a similar time each day? & YES & NO \\
\hline & If YES, when? & & \\
\hline \multirow[t]{4}{*}{ d) } & Who performed the bleeding assessment? & & \\
\hline & Medical staff routinely involved with patient care & YES & NO \\
\hline & Nurses routinely involved with patient care & YES & NO \\
\hline & Trained research staff (nurse, coordinator, assistant) & YES & NO \\
\hline e) & $\begin{array}{l}\text { Were the bleeding assessors blinded to the trial treatment that the patient } \\
\text { was receiving? }\end{array}$ & YES & NO \\
\hline \multirow[t]{2}{*}{ f) } & Was the effectiveness of the blinding assessed? & YES & NO \\
\hline & If YES, how was the assessment done? & & \\
\hline
\end{tabular}




\begin{tabular}{|c|c|c|c|}
\hline \multirow[t]{2}{*}{ g) } & $\begin{array}{l}\text { Did the bleeding assessors receive specific training prior to performing } \\
\text { bleeding assessments? }\end{array}$ & YES & NO \\
\hline & \multicolumn{3}{|l|}{ If YES, what training did they receive (please specify)? } \\
\hline \multirow[t]{2}{*}{ h) } & $\begin{array}{l}\text { Did the bleeding assessors receive further training during the period the study } \\
\text { was open? }\end{array}$ & YES & NO \\
\hline & \multicolumn{3}{|c|}{ If YES, what training did they receive and how frequently did it occur (please specify)? } \\
\hline \multirow[t]{3}{*}{ i) } & Were duplicate bleeding assessments performed? & YES & NO \\
\hline & \multicolumn{3}{|l|}{ If YES, what percentage of bleeding assessments were performed in duplicate? } \\
\hline & $\begin{array}{l}\text { If YES, were results fed-back to bleeding assessors to enhance consistency } \\
\text { between bleeding assessors? }\end{array}$ & YES & NO \\
\hline \multirow[t]{2}{*}{ j) } & $\begin{array}{l}\text { Were guidance notes provided to the bleeding assessors to assist completion } \\
\text { of the bleeding assessment form? }\end{array}$ & YES & NO \\
\hline & If YES, did this include definitions of different types of bleeding? & YES & NO \\
\hline \multirow[t]{2}{*}{ k) } & $\begin{array}{l}\text { If there was more than one bleeding assessor at a trial site, was there a } \\
\text { formalized hand-over system to transfer information between bleeding } \\
\text { assessors? }\end{array}$ & YES & NO \\
\hline & \multicolumn{3}{|l|}{ If YES, what was the system (please specify)? } \\
\hline \multirow[t]{2}{*}{ I) } & Were any other methods used to decrease inter-observer variability? & YES & NO \\
\hline & \multicolumn{3}{|l|}{ If YES, what were they (please specify)? } \\
\hline m) & \multicolumn{3}{|c|}{$\begin{array}{l}\text { What resources were available in the study to support the undertaking of bleeding assessment at } \\
\text { hospitals e.g. how many staff were appointed to perform the bleeding assessment? }\end{array}$} \\
\hline
\end{tabular}




\section{Grading System for bleeding}

\begin{tabular}{|c|c|c|c|}
\hline a) & $\begin{array}{l}\text { Which grading system was used for the adjudication of bleeding, to convert the } \\
\text { results from the bleeding assessment form into a grade? }\end{array}$ & & \\
\hline & WHO (Original 1979 formulation) & YES & NO \\
\hline & Rebulla (1998) & YES & NO \\
\hline & CTCAE version 3.0 & YES & NO \\
\hline & Other (please specify) & YES & NO \\
\hline b) & $\begin{array}{l}\text { Had the grading system selected been modified by the study authors in any } \\
\text { way? }\end{array}$ & YES & NO \\
\hline & If YES, please state in what way it had been modified? & & \\
\hline c) & $\begin{array}{l}\text { Was "significant bleeding" defined by the study authors e.g. WHO grade } 2 \text { or } \\
\text { above? }\end{array}$ & YES & NO \\
\hline & If YES, please state the definition? & & \\
\hline d) & Was life-threatening bleeding defined by the study authors? & YES & NO \\
\hline & If YES, please state the definition? & & \\
\hline e) & $\begin{array}{l}\text { If the grading system reported in the study used red cell transfusions to } \\
\text { partially define the severity of bleeding, was a protocol for red cell transfusion } \\
\text { agreed and used at all sites? }\end{array}$ & YES & NO \\
\hline
\end{tabular}

\section{Converting the Bleeding Assessment into a Bleeding Grade}

\begin{tabular}{|c|c|c|c|c|}
\hline \multirow[t]{6}{*}{ a) } & \multicolumn{4}{|c|}{ How was the bleeding assessment initially converted into a bleeding grade? } \\
\hline & \multirow[t]{5}{*}{ i) } & Manual assignment of grading & YES & NO \\
\hline & & $\begin{array}{l}\text { If YES, was the person assigning the grade blinded to the } \\
\text { intervention? }\end{array}$ & YES & NO \\
\hline & & $\begin{array}{l}\text { Was the bleeding assessment converted into a bleeding grade by the } \\
\text { person who did the original bleeding assessment/ data collection? }\end{array}$ & YES & NO \\
\hline & & If YES, was this grading performed at the bedside? & YES & NO \\
\hline & & $\begin{array}{l}\text { If this was a multicentre study was the bleeding assessment } \\
\text { converted into a bleeding grade centrally, away from the local } \\
\text { participating site e.g. by central coordinating site }\end{array}$ & YES & NO \\
\hline
\end{tabular}




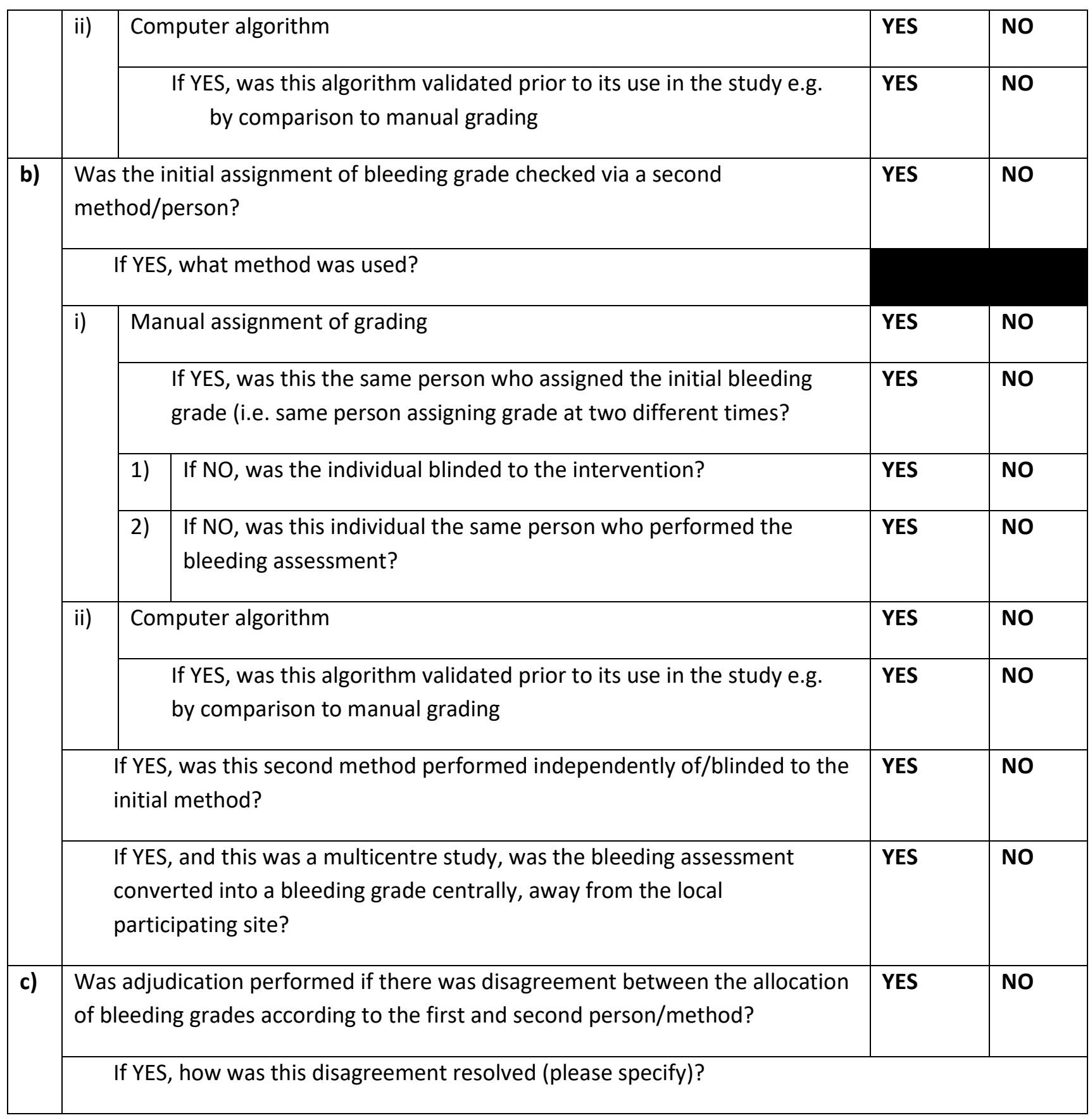


Table A. Assessment of bleeding

\begin{tabular}{|c|c|c|c|c|c|c|c|c|c|c|c|c|c|c|}
\hline \multirow[t]{2}{*}{ First author } & \multirow[t]{2}{*}{ Study } & \multicolumn{5}{|c|}{ Assessment of bleeding } & \multirow{2}{*}{$\begin{array}{l}\text { Frequency } \\
\text { of } \\
\text { assessment }\end{array}$} & \multirow{2}{*}{$\begin{array}{l}\text { Same } \\
\text { time } \\
\text { each } \\
\text { day }\end{array}$} & \multicolumn{4}{|c|}{ Type of bleeding assessors } & \multirow{2}{*}{$\begin{array}{l}\text { Blinding } \\
\text { of } \\
\text { bleeding } \\
\text { assessors }\end{array}$} & \multirow{2}{*}{$\begin{array}{l}\text { Effectiveness } \\
\text { of blinding } \\
\text { assessed }\end{array}$} \\
\hline & & $\begin{array}{c}\text { Patient } \\
\text { notes/chart }\end{array}$ & $\begin{array}{c}\text { Formalized } \\
\text { bleeding } \\
\text { assessment }\end{array}$ & $\begin{array}{l}\text { Examination } \\
\text { of patient }\end{array}$ & $\begin{array}{c}\text { Patient } \\
\text { questionnaire }\end{array}$ & $\begin{array}{c}\text { Nurse } \\
\text { questionnaire }\end{array}$ & & & $\begin{array}{l}\text { Medical } \\
\text { staff }\end{array}$ & Nurses & $\begin{array}{l}\text { Trained } \\
\text { research } \\
\text { nurses }\end{array}$ & $\begin{array}{c}\text { Other } \\
\text { research } \\
\text { investigators* }\end{array}$ & & \\
\hline Cazenave & MIRACLE $^{23}$ & Y & Y & Y & $\mathrm{N}$ & $\mathrm{N}$ & $\begin{array}{l}\text { Twice daily on } \\
\text { day of } T x \text {, } \\
\text { once daily on } \\
\text { day after Tx }\end{array}$ & $\mathrm{N}$ & Y & Y & $\mathrm{N}$ & $N$ & Y & N \\
\hline Heckman & $\begin{array}{l}\text { Heckman et } \\
\text { al } 1997^{1}\end{array}$ & Y & Y & Y & $\mathrm{N}$ & $\mathrm{N}$ & Daily & $\mathrm{Y}$ & Y & Y & $\mathrm{N}$ & $N$ & N & - \\
\hline Heddle & SToP2 & Y & Y & Y & $\mathrm{N}$ & $\mathrm{N}$ & Daily & Y & $\mathrm{N}$ & $\mathrm{N}$ & $\mathrm{Y}$ & Y & Y & $\mathrm{N}$ \\
\hline McCullough & SPRINT ${ }^{3}$ & $\mathrm{Y}$ & Y & $\mathrm{Y}$ & Y & $\mathrm{Y}$ & Daily & Y & $\mathrm{N}$ & $\mathrm{N}$ & Y & $\mathrm{N}$ & Y & $\mathrm{Y}^{+}$ \\
\hline \multirow[t]{2}{*}{ Kerkhoffs } & $\begin{array}{l}\text { HOVON- } \\
\text { Triplate }^{33}\end{array}$ & Y & Y & $\mathrm{Y}$ & $\mathrm{N}$ & $\mathrm{N}$ & Daily & $N$ & $Y$ & $N$ & $N$ & $N$ & $N$ & - \\
\hline & PrePAReS ${ }^{34}$ & $Y$ & $Y$ & $Y$ & $Y$ & $Y$ & Daily & $Y$ & $\mathrm{~N}$ & $N$ & $N$ & $Y$ & $\mathrm{~N}$ & - \\
\hline Rebulla & Trigger ${ }^{4}$ & $Y$ & $Y$ & $Y$ & NR & NR & Daily & $\mathrm{N}$ & $Y$ & $\mathrm{~N}$ & $\mathrm{~N}$ & $\mathrm{~N}$ & $\mathrm{~N}$ & - \\
\hline Slichter & $\mathrm{PLADO}^{5}$ & $Y$ & $Y$ & $Y$ & $Y$ & $Y$ & Daily & $Y$ & $\mathrm{~N}$ & $\mathrm{~N}$ & $Y$ & $\mathrm{~N}$ & $Y$ & $\mathrm{~N}$ \\
\hline Stanworth & TOPPs $^{6}$ & $Y$ & $Y$ & Y & $Y$ & Y & Daily & Y & Y & $N$ & Y & Y & $N$ & - \\
\hline Tinmouth & $\begin{array}{l}\text { Tinmouth et } \\
\text { al } 2004^{7}\end{array}$ & $Y$ & $Y$ & $Y$ & $Y$ & $\mathrm{~N}$ & Daily & $N$ & Y & $N$ & $N$ & $N$ & $\mathrm{~N}$ & - \\
\hline Wandt & $\begin{array}{c}\text { Nuerenberg } \\
\text { trial }^{89}\end{array}$ & $Y$ & $Y$ & $Y$ & $Y$ & $Y$ & Twice daily & $Y$ & Y & Y & $N$ & Y & $N$ & - \\
\hline
\end{tabular}


$\mathrm{Y}=$ Yes; $\mathrm{N}=$ No; $\mathrm{NR}=$ Not reported $; \mathrm{Tx}=$ transfusion

\section{* We did not ask for further details on who these investigators were}

${ }^{\dagger}$ Research nurses asked to detect study units from a panel of 10 platelet components (mixture of study and conventional units). 


\section{Table B: Major differences in WHO grading between studies}

Information from questionnaire, guidance notes sent with CRF and published article

$\mathrm{N}=$ Not defined/present in the study's grading system

* Unexpected bleeding out of normal cycle OR bleeding heavier than normal OR breakthrough bleeding (patient on hormonal therapy) more than spotting

\begin{tabular}{|c|c|c|c|c|c|c|c|c|c|c|c|c|}
\hline \multirow[t]{2}{*}{ First author } & \multirow[t]{2}{*}{ Study } & \multirow{2}{*}{$\begin{array}{l}\text { Occult } \\
\text { blood in } \\
\text { stool }\end{array}$} & \multicolumn{2}{|c|}{ Microscopic blood in } & \multicolumn{3}{|c|}{ Grade 2 skin bleeding } & \multirow{2}{*}{$\begin{array}{c}\text { Retinal } \\
\text { bleeding } \\
\text { without } \\
\text { visual } \\
\text { compromise }\end{array}$} & \multirow[t]{2}{*}{$\begin{array}{c}\text { Grade } 2 \text { vaginal } \\
\text { bleeding }\end{array}$} & \multirow{2}{*}{$\begin{array}{c}\text { Grade } 2 \\
\text { epistaxis/ } \\
\text { bleeding } \\
\text { from } \\
\text { mouth }\end{array}$} & \multicolumn{2}{|c|}{ Hemodynamic instability } \\
\hline & & & Grade 1 & Grade 2 & Petechiae & Purpura & Ecchymoses & & & & Definition & Grade \\
\hline Cazenave & MIRACLE $^{23}$ & Grade 1 & $1+$ & $>1+$ & $\mathrm{N}$ & $>1 \mathrm{~cm}$ & $\mathrm{~N}$ & Grade 2 & $\begin{array}{c}>2 \text { saturated } \\
\text { pads/day }\end{array}$ & $>1 \mathrm{hr}$ & $\mathrm{N}$ & - \\
\hline Kerkhoffs & PrePAReS $^{34}$ & Grade 1 & Positive & $\mathrm{N}$ & $\mathrm{N}$ & $>1$ inch & $\mathrm{N}$ & Grade 2 & $\begin{array}{c}\text { Abnormal vaginal } \\
\text { bleeding* }\end{array}$ & $>30$ mins & $\begin{array}{c}\text { 30-50mmHg fall } \\
>50 \mathrm{mmHg} \text { fall/ } 50 \% \text { fall } \\
\text { in BP }\end{array}$ & $\begin{array}{l}3 \\
4\end{array}$ \\
\hline Heddle & SToP2 & Grade 1 & $1+$ & $>1+$ & $\mathrm{N}$ & $\mathrm{N}$ & $>10 \mathrm{~cm}$ & Grade 2 & $\begin{array}{c}\text { abnormal vaginal } \\
\text { bleeding* }\end{array}$ & $\begin{array}{l}>1 \mathrm{hr} \text { or } \\
\text { packing }\end{array}$ & $\mathrm{N}$ & - \\
\hline McCullough & SPRINT ${ }^{3}$ & Grade 1 & $1+$ & $>1+$ & Generalized & $>1$ inch & $\mathrm{N}$ & Grade 1 & $\begin{array}{c}>2 \text { saturated } \\
\text { pads/day }\end{array}$ & $>1 \mathrm{hr}$ & $>30 \mathrm{mmHg}$ fall & 4 \\
\hline Slichter & PLADO $^{5}$ & $\mathrm{~N}$ & $\mathrm{~N}$ & $\mathrm{~N}$ & $\mathrm{~N}$ & $>1$ inch & $\mathrm{N}$ & Grade 2 & $\begin{array}{l}\text { Abnormal vaginal } \\
\text { bleeding > } \\
\text { spotting }\end{array}$ & $>30$ mins & $\begin{array}{c}\text { 30- } 50 \mathrm{mmHg} \text { fall } \\
>50 \mathrm{mmHg} \text { fall/> 50\% } \\
\text { fall }\end{array}$ & $\begin{array}{l}3 \\
4\end{array}$ \\
\hline Stanworth & TOPPs $^{6}$ & $\mathrm{~N}$ & $\mathrm{~N}$ & $\mathrm{~N}$ & Diffuse & $>5$ & $\begin{array}{c}>10 \mathrm{~cm} \text { or } \\
\text { multiple }> \\
2 \mathrm{~cm}\end{array}$ & Grade 2 & $\begin{array}{c}\text { unexpected } \\
\text { vaginal bleeding } \\
\text { saturating } 2 \\
\text { pads } / 24 \mathrm{hrs}\end{array}$ & $>30$ mins & $>30 \mathrm{mmHg}$ fall & 42 \\
\hline
\end{tabular}


Table C: Conversion to bleeding grade from data

\begin{tabular}{|c|c|c|c|c|c|c|c|c|c|}
\hline First author & Study & $\begin{array}{l}\text { Initial assignment } \\
\text { of bleeding grade }\end{array}$ & $\begin{array}{l}\text { Bleeding assessor } \\
\qquad \text { grader of } \\
\text { bleeding the same } \\
\text { person }^{*}\end{array}$ & $\begin{array}{l}\text { Person who graded } \\
\text { bleeding blinded to } \\
\text { the intervention }\end{array}$ & $\begin{array}{l}\text { Bleeding grade } \\
\text { checked by second } \\
\text { person/method }\end{array}$ & $\begin{array}{l}\text { Method of } \\
\text { checking }\end{array}$ & $\begin{array}{l}\text { Person who } \\
\text { graded bleeding } \\
\text { blinded to the } \\
\text { intervention }\end{array}$ & $\begin{array}{l}\text { Person who } \\
\text { graded bleeding } \\
\text { was blinded to } \\
\text { the initial grade }\end{array}$ & $\begin{array}{c}\text { Was adjudication } \\
\text { performed if } \\
\text { differences in } \\
\text { bleeding grade }\end{array}$ \\
\hline Cazenave & MIRACLE ${ }^{23}$ & Manual & $\mathrm{Y}$ & $\mathrm{Y}$ & $\mathrm{N}$ & - & - & - & - \\
\hline Heckman & $\begin{array}{c}\text { Heckman et al } \\
1997^{1}\end{array}$ & Manual & $\mathrm{Y}$ & $\mathrm{N}$ & $Y$ & Manual & $\mathrm{N}$ & NR & $Y$ \\
\hline Heddle & STOP2 & Manual & $\mathrm{Y}$ & $\mathrm{Y}$ & $\mathrm{Y}$ & Manual & $\mathrm{Y}$ & $\mathrm{Y}$ & $\mathrm{Y}$ \\
\hline \multirow[b]{2}{*}{ Kerkhoffs } & Triplate $^{33}$ & Manual & $Y$ & $\mathrm{~N}$ & $\mathrm{Y}$ & Manual & $\mathrm{N}$ & $\mathrm{N}$ & $\mathrm{Y}$ \\
\hline & PrePAReS ${ }^{34}$ & Manual & $\mathrm{N}$ & $\mathrm{Y}$ & $\mathrm{Y}$ & $\begin{array}{l}\text { Computer } \\
\text { algorithm' }\end{array}$ & - & - & $\mathrm{Y}$ \\
\hline Rebulla & Trigger $^{4}$ & Manual & $Y$ & $\mathrm{~N}$ & $\mathrm{~N}$ & - & - & - & - \\
\hline Slichter & PLADO $^{5}$ & $\begin{array}{l}\text { Computer } \\
\text { algorithm }\end{array}$ & - & - & $N$ & - & - & - & - \\
\hline Stanworth & TOPPs $^{6}$ & $\begin{array}{l}\text { Computer } \\
\text { algorithm }\end{array}$ & - & - & $N$ & - & - & - & - \\
\hline Tinmouth & $\begin{array}{c}\text { Tinmouth et al } \\
2004^{7}\end{array}$ & Manual & $\mathrm{Y}$ & $\mathrm{N}$ & $Y$ & Manual & $\mathrm{Y}$ & $\mathrm{Y}$ & $Y$ \\
\hline Wandt & Nuerenberg trial ${ }^{89}$ & Manual & $\mathrm{N}$ & $\mathrm{N}$ & $\mathrm{Y}$ & Manual & $\mathrm{N}$ & NR & $\mathrm{Y}$ \\
\hline
\end{tabular}

Results from the 11 questionnaires 


\section{* Question was only answered if method of assessing bleeding was manual}

${ }^{+}$This was resolved mainly by discussion between the two graders or between the graders and Principal Investigator/Chief Investigator

₹ Validated prior to commencement of the study 


\section{Appendix 3 :BEST Collaborative Members}

\section{Chair}

Larry Dumont
Past Chair and Treasurer

Lorna Williamson
Cellular
Therapy

Zbigniew Szczepiorkowski

David McKenna

JoAnna Reems

Ronald Sacher

Dominic Wall

David Stroncek

Henk Garritsen

Minoko Takanashi

Daniel Hollyman

\author{
Clinical \\ Studies
}

Conventional
Components

Transfusion

Safety

\section{Team Leaders}

Nancy Heddle

Alan Tinmouth
John Hess

Pieter van der Meer
Michael Murphy

Mark Fung

\section{Scientific Members}

Tor Hervig

Miguel Lozano

Andreas Greinacher

Leo van de Watering
Rebecca Cardigan

Dana Devine

Hans Gulliksson

Sherrill Slichter
Sunny Dzik

Richard Haspel

Richard Kaufman

Simon Stanworth

\section{Associate Scientific Members}

\author{
Donald Arnold \\ Jonathan Waters \\ Alyssa Ziman \\ Meghan Delaney
}

Jose Cancelas

Dirk de Korte

Rosemary Sparrow

Ralph Vassallo
Neil Beckman

Jay Brooks

Joan Cid

Mark Yazer

\section{Honorary Members}

Georges Andreu James P. AuBuchon Morris Blajchman Anneke Brand Marcela Contreras Neelam Dhingra Janny de Wildt-Eggen Hermann Eichler Andrew Heaton

\author{
Margarethe Heiden \\ Riitta Kekomaki \\ Harvey Klein \\ Maurice Masse \\ Wolfgang Mayr \\ Jeffrey McCullough \\ Gary Moroff \\ Paul Ness
}

\author{
Derwood Pamphilon \\ Ruby Pietersz \\ Chris Prowse \\ Martin Ras \\ Paolo Rebulla \\ Jerard Seghatchian \\ Girolamo Sirchia \\ Cees Smit Sibinga
}

\author{
Irena Sniecinski \\ Joseph Sweeney \\ Shigeru Takamoto \\ Jaro Vostal \\ Girish Vyas \\ Wolfram Walker \\ Silvano Wendel \\ Sam Wortham
}

